\title{
A COMPARATIVE POLICY ANALYSIS OF WIND FARM DEVELOPMENT STRATEGIES IN ONTARIO AND GERMANY
}

by

Leo Lau, Bachelor of Environmental Studies Geography, University of Waterloo, 2005

\author{
Masters Research Project \\ Presented to Ryerson University \\ in partial fulfillment of the requirements of the degree of \\ Master of Applied Science \\ in the Program of \\ Environmental Applied Science and Management \\ Toronto, Ontario, Canada, 2014 \\ CLLeo Lau 2014
}


I hereby declare that I am the sole author of this Masters Project Paper. This is a true copy of the Masters Project Paper, including any required final revisions.

I authorize Ryerson University to lend this Masters Project Paper to other institutions or individuals for the purpose of scholarly research.

I further authorize Ryerson University to reproduce this Masters Project Paper by photocopying or by other means, in total or in part, at the request of other institutions or individuals for the purpose of scholarly research.

I understand that my Masters Project Paper may be made electronically available to the public. 
A Comparative Policy Analysis of Wind Farm Development Strategies in Ontario and Germany

Leo Lau, 2014

Master of Applied Science

Environmental Applied Science and Management

Ryerson University

\begin{abstract}
Wind farm development strategies are compared with respect to gaining public acceptance between Ontario and Germany. Public opposition to wind farm development is currently experienced in Ontario and strategies employed by Germany to mitigate public opposition and gain public acceptance have been proven to be effective. These two jurisdictions are comparable due to similar jurisdictional responsibility for renewable energy development and implementation of climate change goals. Historical factors have been shown to trigger wind farm development for Ontario and Germany but certain historical events have played a larger impact to public acceptance in Germany. Germany has been able to maintain and increase the level of public acceptance to wind farm development by utilizing inclusive planning legislation and encouraging community based incentives. Ontario has developed legislation to increase wind farm development but has increased wind farm opposition. Ontario could increase public acceptance to wind farm development by learning from Germany's experiences.
\end{abstract}




\section{Table of Contents}

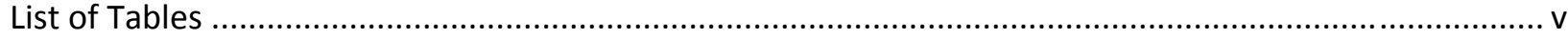

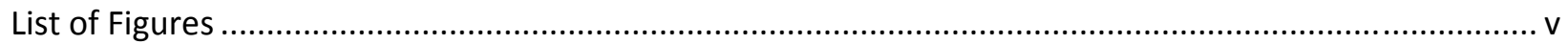

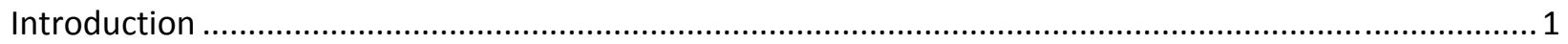

Wind Farm Development Opposition Cases in Ontario ...................................................... 4

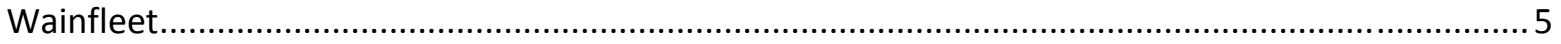

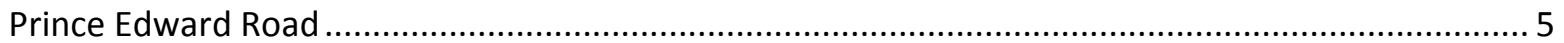

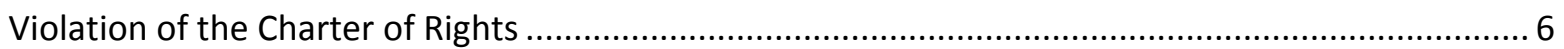

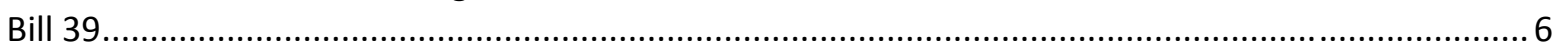

Policy \& Participation Comparative Analysis .......................................................................... 7

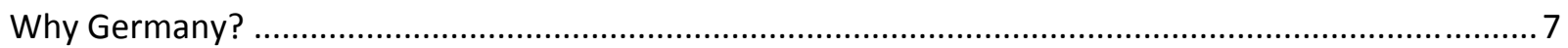

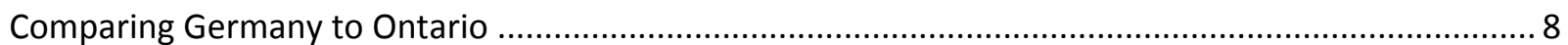

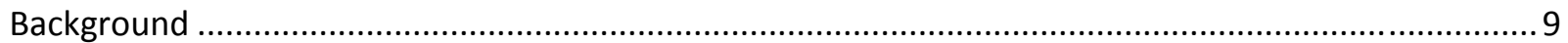

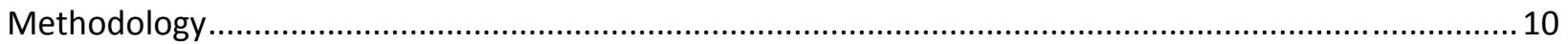

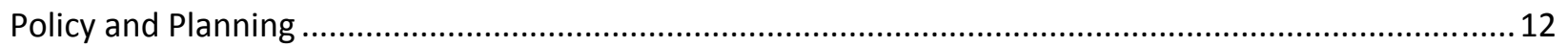

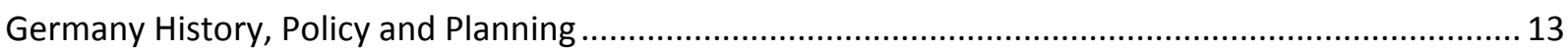

Power Generation Past and Renewable Energy History .................................................... 13

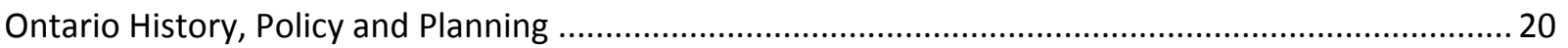

Ontario Power Generation Past ................................................................................... 20

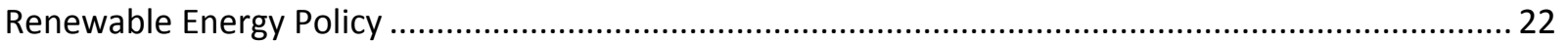

Former Environmental Assessment Process for Renewable Energy Projects ..................................23

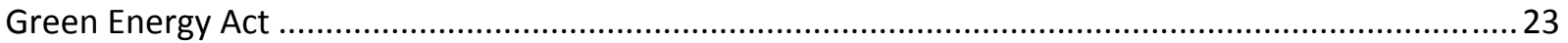

Future Policy and Planning Direction ........................................................................ 26

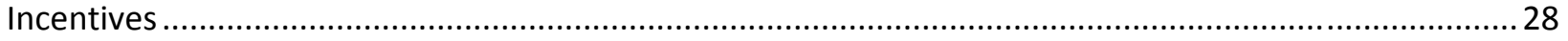

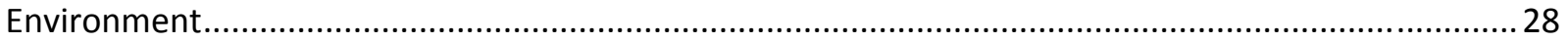

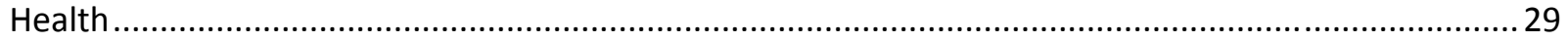

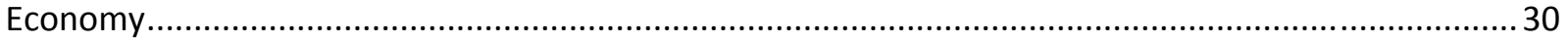

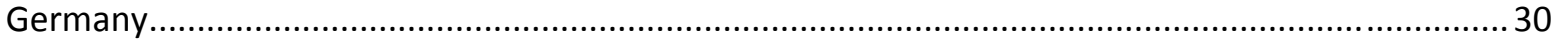

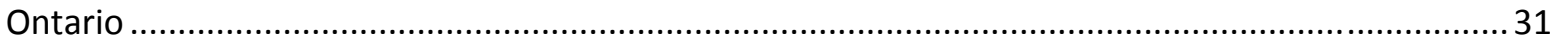

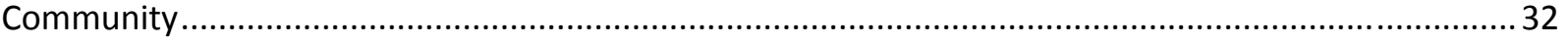

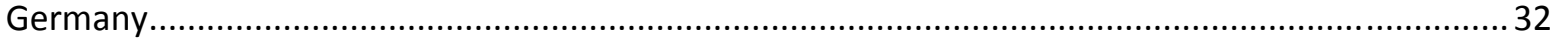

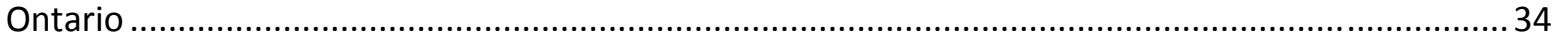

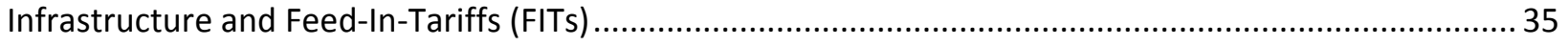

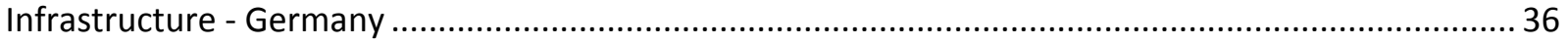

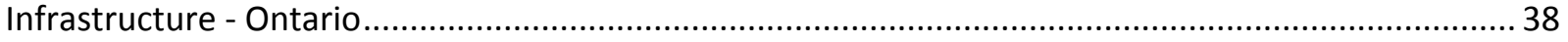

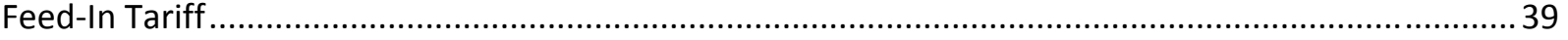

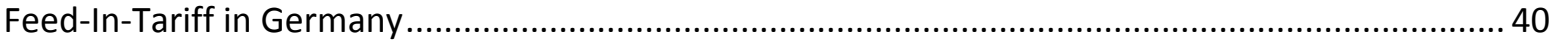




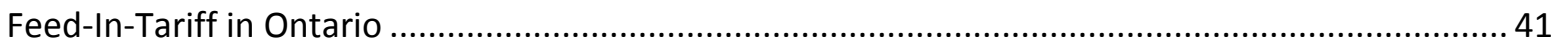

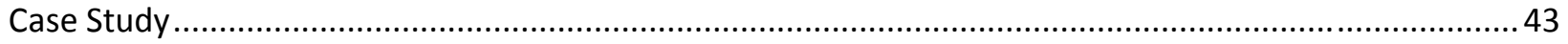

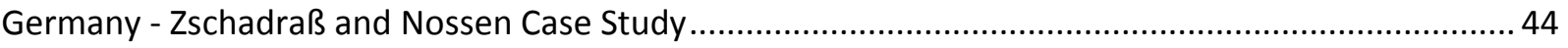

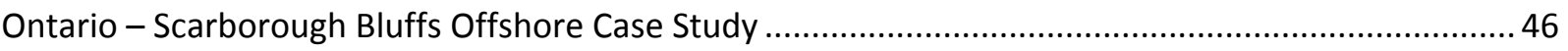

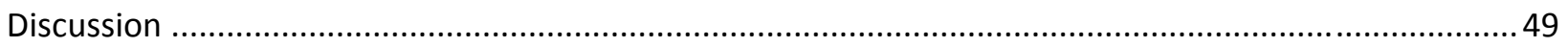

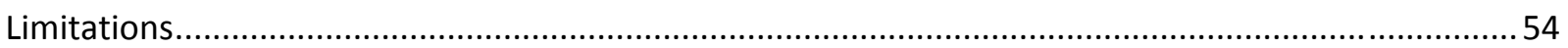

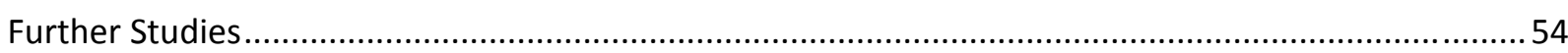

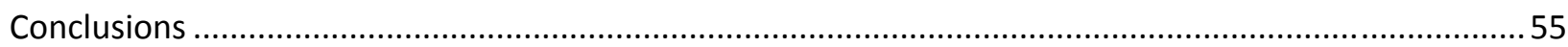

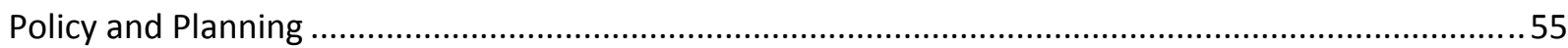

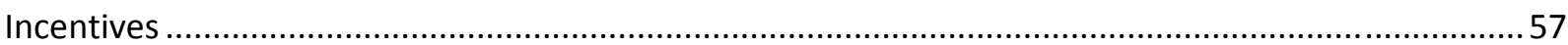

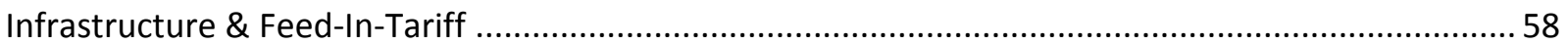

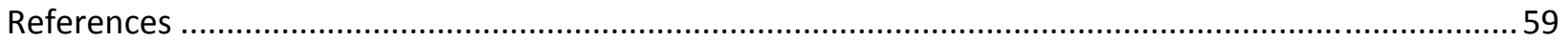

\section{List of Tables}

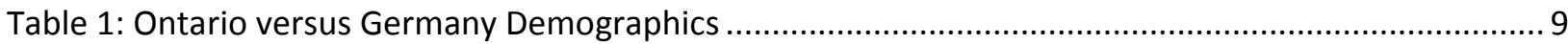

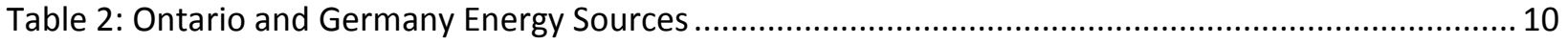

Table 3: German Installed Wind Capacity and Rate of Change from 1998 to 2012 ................................ 18

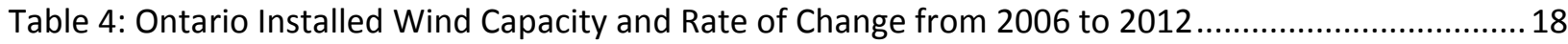

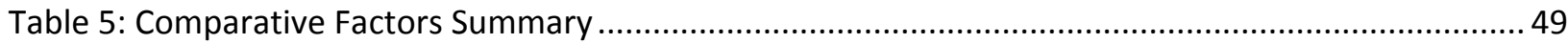

\section{List of Figures}

Figure 1: Renewable Create More Jobs than Conventional Energy Does .............................................. 31

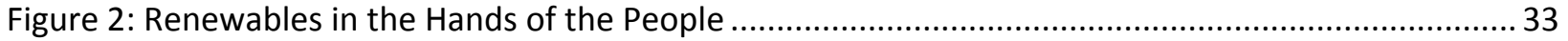




\section{Introduction}

Fossil fuels have dominated the world for centuries as a primary source of energy due to their abundance and fairly inexpensive cost. Although many factories, transportation modes, and other industries enjoy the benefits of the energy created by fossil fuels, there are several drawbacks, such as the generation of greenhouse gas emissions from the combustion by-products of fossil fuels. The common by-products from these emissions such as $\mathrm{CO}_{2}, \mathrm{NOx}, \mathrm{SO}_{2}$, and fine particulate matter contribute to the detriment of the environment in the form of greenhouse gas, climate change, acid rain and poor air quality. These environmental issues can cause further problems, including increasing sea levels, frequent storms, human health problems such as respiratory ailments, and harm to wildlife and their respective habitats. In addition to environmental impacts caused by fossil fuel use, the rise in the cost of fossil fuels in recent decades has begun to cause decision makers to seek alternative forms of energy.

One of the alternatives decision makers are seeking out is renewable energy. Renewable energy is a form of energy which originates in the natural environment and includes wind, sun, geothermal activities, and tides as sources. The transition towards renewable energy was triggered by a greater awareness of and concern about global warming, climate change, and the increase in fossil fuel costs. The renewable energy movement has been gaining momentum in the last few decades with billions of dollars in investments for research and development, manufacturing, jobs, and infrastructure.

The member states of the European Union are shifting towards a low carbon economy by setting a national renewable energy target to have $20 \%$ renewable energy produced by 2020 . To achieve this goal, 60 to 70 billion Euros of investment is needed for research and development. This goal would require strong political support (Kitzing et al., 2012). 
Ontario has been recently increasing the use of renewable energy sources to satisfy the province's electricity demands. This renewable energy initiative will enable the Liberal Government's plan to phase out coal powered plants by 2014 (Ministry of Energy, 2012). As of January 2014, the Thunder Bay Generating Station is currently the last remaining coal powered plant in operation and is expected to be shutdown in mid-2014 (Ontario Power Generation, 2014).

The Liberal Government is confident that renewable energy is a viable option to replace coal power since it provides many environmental, health, and economic benefits over coal power. The direct and indirect results of using renewable energy over coal energy are a decrease of pollutants that cause smog and acid rain, a decrease in respiratory health problems, reduced greenhouse gas emissions, and a reduction in costs associated with mitigating air pollution (Ministry of Energy, 2012).

Wind energy will be the alternative energy source focused on in this study as the government of Ontario is currently employing it and there have been controversies regarding it from wind energy opposition groups. These opposition groups have voiced their concerns using various forms of media and have also protested in public venues including Queens Park (Newswire, 2012). Wind turbine development in Ontario is considered controversial in many communities. Public opposition to wind turbine development is common when wind farm developments are proposed. Critics have argued that wind turbines decrease property values, disrupt natural landscapes and wildlife, and cause health problems to people situated near them. Wind turbine proponents have difficulty in managing wind turbine conflicts and gaining community acceptance for siting wind turbines.

The main health effects claimed by wind farm opponents include headaches, insomnia, loss of concentration, and anxiety. Ontario's Chief Medical Officer of Health's position is that wind turbines do not cause human health problems, a conclusion which is widely debated by wind farm opponents. The topic of human health and wind turbines has become a prominent issue since a health study was 
commissioned by Health Canada in 2012. This study's findings are expected to be published in 2014 and will determine if wind farms cause human health impacts. Wind farm opponents are optimistic that the results will conclude wind farms cause negative human health impacts, thereby reinforcing their views that wind farms should not be developed (CBC, 2013). However, wind farm proponents believe this study will demonstrate there are no health impacts associated with wind farms, resolving this issue. This topic in itself is a study on its own and will not be discussed in detail. However, it is important to remember human health is commonly used as a reason to oppose wind farm development even though conclusive evidence is not yet available.

Large scale wind farm development requires large amounts of land and height to optimally operate. Wind speeds are stronger at higher altitudes and are best suited to produce the most power. The requirements for successful wind farm development have resulted in landscapes being populated by large wind farms. These visual landscape changes are unsettling to affected community members and are one of the reasons why wind farm development is not favoured in these communities. The perception by wind farm opponents of this change in the landscape is that it will result in a devaluation of property value.

The purpose of this study is to compare what strategies have been used in Germany and Ontario for wind development and examine which of them are more effective in gaining public acceptance. The objectives of this study are to examine Ontario and Germany's wind energy policy history which will provide context for each jurisdiction's goals, policies, strategies, successes, and failures. It is expected that history will play a pivotal role in each jurisdiction's policymaking. Another objective is to compare incentives and determine their effectiveness of mitigating opposition and gaining public acceptance. The distribution of benefits and compensation between wind farm development and the affected communities are expected to play a key factor for comparing each jurisdiction. Wind farm infrastructure 
and feed in tariffs ("FIT") will be examined since these elements play a role in who would finance wind farms and how they impact public attitudes. Policy making, planning, incentives, and infrastructure are the four (4) key factors that will be analyzed to provide an explanation of what effective strategies should be used to improve public acceptance. In the last decade, Ontario began wind farm development to shift to a low carbon economy, but this has led to wind farm opposition. The next section will provide some examples of the lengths to which public opposition groups will go to stop wind farm development.

\section{Wind Farm Development Opposition Cases in Ontario}

There have been several cases in Ontario where wind farm opponents have taken their cases to court in the hopes of legally rejecting wind farm developments. This is their only option since municipalities have lost control of their ability to disapprove of these projects. An explanation of the municipality's ability to reject wind farm development will be discussed in further detail later in the Ontario Green Energy Act (GEA) section. This section will discuss several court cases and decisions in Ontario to demonstrate the commitment of opposition groups to prevent wind farm development in their respective communities.

Opponents are quite persistent in using Ontario's legal system to halt wind farm development. There has been limited success challenging projects or Renewable Energy Approvals (REA) since it has been difficult to prove to the Environmental Review Tribunal (ERT) that wind farms are violating the Environmental Protection Act (EPA).The ERT is an independent and impartial tribunal created by the Province of Ontario. The main role of the ERT is to provide public hearings and decide on matters regarding orders, approvals, licenses, and permits relating to specific legislation, including but not limited to, the Environmental Protection Act, Clean Water Act, Safe Drinking Water Act, and Pesticides Act (Environmental Review Tribunal, 2013). A REA is an approval which must be obtained by wind farm 
proponents for wind farm development. The REA is issued by the Ministry of Environment (MOE) as a requirement in Ontario Regulation 359/09 created under the EPA (Walker, 2013).

\section{Wainfleet}

The Township of Wainfleet created a municipal by-law on April 10, 2012, to prevent wind farm development from occurring within its municipal boundaries. The by-law did not explicitly mention prohibiting wind farm development within Wainfleet but created requirements for wind farm development that are very difficult to fulfill. There are three core provisions within this by-law: 1) all industrial wind turbines within the Township are subject to a minimum setback distance from any property; 2 ) noise emitted from any industrial wind turbine within the Township may not exceed $32 \mathrm{~dB}$ at the nearest property; and 3) the wind farm developer must provide a $100 \%$ indemnification for any property value loss or any adverse health effect caused by an industrial wind turbine (Timmins \& Smeijers, 2013).

The Ontario Superior Court of Justice recently determined the anti-wind by-law was invalid due to its vagueness and uncertainty. The term "property" was not clear and did not define who was considered an "inhabitant". Also, this by-law would conflict with the GEA (Saxe, 2013a).

\section{Prince Edward Road}

The first rejection by the ERT under s.142.2 (1) of the EPA occurred in July 2013. The ERT can reject a wind farm development if the project has potential to cause serious harm to human health or serious irreversible harm to plant life, animal life and the natural environment.

In the case of Prince Edward County, the ERT rejected the REA on the basis that the road to the wind farm would negatively affect an existing population of turtles in the area, and not the actual wind farm development. The REA did not satisfy the ERT requirements by providing a mitigation plan to prevent harm to the turtles (Sahni \& McCutcheon, 2013). 


\section{Violation of the Charter of Rights}

The Municipality of North Middlesex attempted to use the Charter of Rights and Freedoms to reject a wind turbine development. Their argument cited s.7 of the Charter which states "Everyone has the right to life, liberty and security of the person and the right not to be deprived thereof except in accordance with the principles of the fundamental justice." The municipality's reasoning was that certain sections of the EPA were unconstitutional since it required the wind farm opponent to prove the likelihood of harm to human health. The ERT dismissed the municipality's claim since the municipality is considered a corporation and not an individual; meaning, the municipality cannot claim the same rights as an individual can under the Charter of Rights (Saxe, 2013b).

\section{Bill 39}

Opposition to wind farm development has not been limited to communities. There has been mixed opinion among political parties in Ontario about wind power and renewable energy. The Progressive Conservative Party of Ontario has been opposed to wind farm development in the province. The party's main arguments include the cost of the FIT system, threats to wildlife, and the suspicion that turbines are the cause of adverse health effects (Ontario PC, 2012). In March 2013, the Progressive Conservative party introduced Bill 39 to revoke the GEA. The bill would only allow wind turbines to be developed with authorization from the municipality. If the bill had been passed, it would have terminated the feed-in tariff program and prevented the Ontario Power Authority (OPA) from entering non-profitable renewable energy contracts. Lastly, the bill would have removed amendments to the Planning Act, which exempted renewable energy projects from policy statements, provincial plans, official plans and zoning by-laws (Saxe, 2013c). 


\section{Policy \& Participation Comparative Analysis}

\section{Why Germany?}

In contrast to the issues faced in Ontario, Germany has had many successful wind turbine developments and enjoyed high levels of local acceptance for wind turbine projects. Germany was chosen to be compared to Ontario with respect to wind development strategies, because Germany is regarded as a world leader in renewable energy, especially in wind farm development. Germany ranks third in the world for installed wind capacity with approximately $31,332 \mathrm{MW}$, behind China with 75,564 MW and the United States with 60,007 MW (Global Wind Energy Council, 2013). The share of renewable energy which accounts for Germany's electricity production has doubled from $6.3 \%$ in 2000 to $11.6 \%$ in 2006 (Büsgen \& Dürrschmidt, 2009). At the end of 2012, renewable energy production rose to $21.9 \%$ of Germany's total energy production (BDEW, 2013). In the last few years, the media have highlighted Germany's commitment in promising to decommission all nuclear power plants in the country and move towards renewable energy.

Germany was selected rather than China since Ontario and Germany share similar policies and climate change goal initiatives and both are working to shift towards a low carbon economy. China does not currently have any climate change goals to reduce greenhouse gas emissions (Heneghan, 2014). In the United States, each state is responsible for their renewable energy policies with respect to financial incentives, rules and regulations (Delmas, 2011). This jurisdictional responsibility of renewable energy between the state and federal level is the reason why the United States was not used to compare to Ontario.

Although Germany and Ontario have both defined climate change goals and policies, they do not have the same targets. Germany was also one of the first jurisdictions to develop and successfully implement the Feed-In Tariff (FIT) program to provide a means for the government to increase 
investment in wind power. The FIT compensates energy producers by offering a higher cost per kilowatt hour generated to off-set high initial capital costs. Similarly, Ontario is also using FIT as a mechanism to encourage wind farm development.

Germany's public acceptance of wind power and renewable energy is well known, especially in recent years as there have been strong popular movements to shift away from the use and operation of nuclear power plants within Germany. Germany's communities are not only more accepting of wind farm developments, but also in some instances request wind farms to be developed in their vicinities. Ontario on the other hand has experienced a lot of resistance wind farm development in communities where these developments have been proposed. The similarities and differences between these two jurisdictions will be compared and contrasted to determine what policy differences have been effective in gaining public acceptance and reducing opposition for Germany and what Ontario might have done to improve public acceptance.

\section{Comparing Germany to Ontario}

A comparison of national wind farm development strategies between Canada and Germany was not conducted in this study due to each jurisdiction's responsibilities of renewable energy policy development. In Germany, the German federal government is responsible for the entire country's energy management and decision making (BMWI, 2012).In Canada, each province is responsible for its own energy management according to Part 92A of Canada's Constitution (Canadian Legal Information Institute, 2012).Therefore these two jurisdictions, Ontario and Germany, are both responsible for managing transmission, distribution, FIT, ensuring reliable supply and encouraging renewable energy development (Practical Law, 2013). Ontario and Germany's jurisdictional responsibilities for energy policy development and implementation are the same and this allows a proper comparison between them. 


\section{Background}

In terms of land mass, Germany is almost three times smaller than the province of Ontario with six times the population. Although Germany has less space and more population than Ontario, Germany has fifteen times the number of wind turbines (approximately 31,000 MW) and Ontario uses 1.6 times more energy than Germany on a per capita basis. Table 1 shows Ontario and Germany's population, land mass, electricity consumption per capita, and installed wind capacity.

Table 1: Ontario versus Germany Demographics

\begin{tabular}{|c|c|c|}
\hline & Ontario* $^{*}$ & Germany $^{* *}$ \\
\hline 2010 Population (millions) & 13.2 & 81.7 \\
\hline Land Mass (thousand sq km) & 895 & 350 \\
\hline 2010 Electricity Consumption per capita (kWh)* & 10,700 & 7,200 \\
\hline 2012 Installed Wind Capacity (MW) ** & 2,043 & 31,000 \\
\hline
\end{tabular}

[*Source: (Statistics Canada, 2012), (IESO, 2012), (CanWEA, 2013)], [**Source: (The World Bank, 2013), (The World Bank, 2013), (Global Wind Energy Council, 2013)]

Table 1 suggests that Germany is successful in the installation of a greater number of wind energy developments while having less land mass and more population than Ontario.

In terms of energy sources, the ones utilized in Ontario and Germany are quite different from one another with the exception of natural gas. Table 2 illustrates the distribution of energy sources for each jurisdiction as of 2012. It is interesting to see that Ontario's use of coal is much lower than Germany's but the opposite is true for nuclear power. The reason for the reduction of coal power is discussed later in this study. The Ontario government has recently announced it will not make any new investments in new nuclear reactors and plans to only refurbish existing ones (Radwanski, 2013). 
Table 2: Ontario and Germany Energy Sources

\begin{tabular}{|c|c|c|}
\hline Energy Type & Ontario (\%)* & Germany (\%)** $^{* *}$ \\
\hline Nuclear & 56 & 44.7 \\
\hline Coal & 3 & 11.3 \\
\hline Gas & 15 & 3.2 \\
\hline Hydro & 21 & 7.7 \\
\hline Wind & 3 & 4.6 \\
\hline Solar & 1 & 6.9 \\
\hline Biogas & 1 & 6 \\
\hline Other & 1 & \\
\hline
\end{tabular}

[*Source: (IESO, 2012)] [**Source: (BDEW, 2013), (Federal Ministry for the Environment, Nature Conservation and Nuclear Safety,2013)]

More recently, Germany has elected to shutdown nuclear power plants and will continue to rely

on coal power as a temporary source of energy until renewable sources are able to meet the country's

full energy demands. According to the International Energy Agency, as of 2013, there are currently

several large coal generation plants under construction across Germany (IEA, 2013). Further

examination of Germany's plans to remove nuclear power as a source of energy will be explained later

in the German section of the Policy and Planning section.

\section{Methodology}

This study is a policy comparison between Ontario and Germany's wind farm development strategies and involves four key factors: policy, planning, incentives, as well as infrastructure and FeedIn-Tariffs. This comparison will provide an explanation of the differences in the public's acceptance of wind farm development in Ontario and Germany.

The policy and planning factors will be combined in one section and each jurisdiction will be examined separately. Although policy and planning factors are different, the two factors are historically tied to one another. A historical overview will be given to provide context of events and circumstances that triggered the formation of renewable energy policy and legislation. 
A variety of Incentives for wind farm development from each jurisdiction will be presented and compared. Comparing each jurisdiction's incentives will provide an understanding of which incentives have been employed successfully to gain public acceptance.

The Infrastructure and Feed-In-Tariff section will follow the same format as the Incentive section. Wind farms would be useless without transmission infrastructure and effective distribution networks to transport the energy generated from the source to the grid. Currently, the older infrastructure that is in place would not have the capacity to handle the new energy sources in both jurisdictions. This section investigates what is currently being done, what is planned for the future, and the amount of investment that is allocated to infrastructure. In addition to the Infrastructure, Ontario and Germany's FIT programs will be examined to determine their effectiveness and the level and extent of influence on public acceptance or opposition. However, the study will not include FIT pricing analysis or economic modelling to determine which jurisdiction possesses the better FIT program as this topic is quite extensive since it encompasses all types of renewable energy (including biomass, solar, and hydro) and is outside the scope of this study.

This study includes a case study from Ontario and Germany which will demonstrate the causes of public opposition, issues, and public acceptance. The case study in Germany will examine two towns; one town's strategy is similar to Ontario's wind farm development and while the other town employed the traditional German strategy. The case study in Ontario will examine the causes, failures, and outcomes of offshore wind farm development at the Scarborough Bluffs. An offshore wind farm case study was compared to an onshore wind farm case study to demonstrate that the offshore wind farm should have had less opposition due to the large setback requirements which would have made noise and health impacts an innocuous issue. 
The discussion section will compare all these factors to determine similarities and differences between the two jurisdictions and examines which factors have been successful for Germany.

Understanding each of the factors, could assist government and developers in changing public attitudes related to wind turbine development in Ontario and improve the wind farm development process. The result could potentially cause Ontario communities to eventually start taking the initiative, like their German counterparts, and reach out to developers for wind power instead of developers subjecting residents to them. Therefore it is important to investigate the factors which made Germany so successful in wind farm development and what strategies are used for successful implementation. This will also involve researching problems that have arisen and how these issues were resolved. It will also determine whether Ontario will be able to implement Germany's strategies. Successful low carbon transition and wind farm implementation strategies used in Germany could be recommended.

The main sources of information have been derived from academic journals, government publications, law newsletters, industry publications, and newspapers. German information has been generally accessible as it has been translated to English.

As mentioned earlier, this study will not investigate whether wind turbines cause human health effects. Also, this study will not examine the effectiveness of wind turbines as an energy source. Many studies have investigated wind turbines as viable sources of energy because they are known to have intermittent production abilities.

\section{Policy and Planning}

Public policy is defined as a system of laws, regulatory measures, and funding priorities that address specific public issues. Municipal, state/provincial, and federal government bodies all develop and implement policies to benefit their society (Kilpatrick, 2000). Government policies determine the 
decision making direction for political entities. Germany and Ontario's leaders at all levels of government are democratically elected by residents in their respective constituencies. The government in office typically represents the majority voters. Generally, the policies created by politicians should reflect the consensus at that level of government. In Ontario and Germany's cases, each respective government had a variety of reasons to promote renewable energy sources. Renewable energy policies were created to move the province/country towards a low carbon economy. Some reasons include reducing $\mathrm{CO}_{2}$ emissions, economic reasons, or reducing the use of nuclear power.

\section{Germany History, Policy and Planning}

\section{Power Generation Past and Renewable Energy History}

From the end of World War II until the 1970s Germany relied on fossil fuels and nuclear power as their energy sources. The oil crisis in 1974 was a trigger for Germany to develop a renewable energy policy. For approximately fifteen years, this renewable energy policy focused on research and development of renewable energy such as training personnel, development of prototypes, and laboratory production (Lauber \& Mez, 2006).

In 1982, the German government spent approximately $€ 150$ million a year at the peak of this research and development stage. This amount was scheduled to drop to €86 million in 1986 since the government began to shift away from renewable energy. The German government was transitioning to mainly nuclear power. Although the renewable energy budget was scheduled to drop in 1986, this never happened due to the Chernobyl nuclear meltdown incident (Lauber \& Mez, 2006).

The Chernobyl nuclear incident had a profound and lasting effect on the German population's opinion of nuclear power. The public opinion towards nuclear power became negative and two years after the accident, nuclear energy opposition increased to more than $70 \%$ of the population and support 
dropped to approximately $10 \%$. Before the Chernobyl accident, support and opposition for nuclear power was evenly divided in public opinion (Lauber \& Mez, 2006).

After the Chernobyl incident, the German government re-evaluated its renewable energy policy and moved to wind energy. Denmark served as a role model on how to effectively implement reliable small scale wind power plants. An added benefit was that wind turbines were manufactured and operated by Germans so it was economically favourable to make the transition. Wind turbine groups and collectives which consisted of farmers, co-ops, and towns, were established to raise investment capital for wind turbines and development. The German people became motivated to produce their own energy and become less dependent on importing from other producers (Bruns \& Ohlhorst, 2011). The initial wind farms did not have a clear regulatory approval process. Wind energy was still considered to be a newer and less familiar energy source rather than an independent energy sector. The Germans knew that further refinement of wind turbine technology would be required for widespread use.

In the early 1990s, Germany set climate change initiatives to reduce its national greenhouse gas emissions. The German government began setting climate change goals in order to reduce greenhouse gas emissions, a $30 \%$ reduction of 1987 levels of $\mathrm{CO}_{2}$ and methane emissions by 2005 , reaching $80 \%$ by 2050. In 2007, renewable energies were able to reduce $\mathrm{CO}_{2}$ emissions by 115 million metric tons (Ohl \& Eichhorn, 2010). Major reforms to energy policy were created to help achieve the goals that the government set. The German government spent more than $€ 1$ billion on renewable energy research between 1990 and 1998 (Lauber \& Mez, 2006). The German wind energy industry increased more than ten times from 1991 to 1995, and installed capacity grew from 106 MW to 1,120 MW (Bruns \& Ohlhorst, 2011).

There was a two year slump in the wind industry due to market instability and uncertainty for investors due to the power companies appealing the "Electricity Feed-In Act". Power companies did not 
want to be legally required to compensate wind producers feeding energy into the grid. The Electricity Feed-In Act was replaced by the German Renewable Energy Act (Erneuerbare-Energien-Gesetz [EEG]) in April, 2000. The EEG was subsequently amended in 2004, 2009 and 2012 (Büsgen \& Dürrschmidt, 2009). The purpose of the EEG was to promote the development of renewable energy supply and increase renewable energy consumption by at least $35 \%$ by 2020 and to $80 \%$ by 2050 (Federal Ministry for the Environment, Nature Conservation and Nuclear Safety, 2013).

There are three main principles in the EEG that enable the promotion and encouragement of renewable energy development projects. The purpose of the first principle was to ensure secured renewable energy investments by guaranteeing FIT and priority grid connections. This would provide renewable energy producers set prices and every kilowatt generated would be compensated for the next twenty years. The second principle's purpose was to encourage innovation by gradually reducing the FIT program benefits. As tariffs are reduced for renewable energy facilities, this would cause renewable energy manufacturers to become more cost competitive through technological innovation. The third principle ensured the cost of renewable energy would not be a burden on the public's "purse". The intention of this principle was to prevent renewable energy from becoming subsidized through taxes, as the costs would be passed onto consumers. The thought process behind this was fairness, as those who use the most electricity should pay the most for its usage (German Renewable Energies Agency Information Platform, 2013).

The German EEG has become a model for other states in the European Union (EU) as it is used a framework for renewable energy development and financing. For example, nineteen of the twenty seven member states of the EU have adopted the EEG model into their respective national acts and legislation to help encourage renewable energy development (German Renewable Energies Agency Information Platform, 2013). 
During the market slump in the mid-1990s, Germany began experiencing some opposition to wind turbine projects due to noise emissions, impacts to wildlife, and visual impacts to the local landscape from communities. In addition to these concerns, the growth of wind turbine developments exceeded the communities' comfort levels (Bruns \& Ohlhorst, 2011). Wind turbine development projects started to become hampered by environmental restrictions and community opposition.

In 1998, the German government amended planning laws to accommodate wind turbine developments in communities in order to reach Germany's climate change goals. This was done to both achieve increased wind farm development while being transparent and mitigating conflicts (Geißler et al., 2013). The German government recognized that regional planning was essential in combining their federal goals with those at the local municipal level (Ohl \& Eichhorn, 2010). The regional planning level dealt with the placement of land use activities, infrastructure, and development of commercial, industrial and residential areas (Ohl \& Eichhorn, 2010).

These new amendments created to increase acceptance for wind farm development led to preemptive siting policies and they relieved regional planners of the increasing pressure from developers and communities. Initially, in the 1990s, the German wind farm development process was a bilateral process between the wind power developers and local municipalities and was similar to the process currently used in Ontario. This pre-emptive siting policy created a different planning scheme and gave wind turbines precedence over other types of land uses. These specify wind turbines are not allowed to be built outside of these designated areas (Ohl \& Eichhorn, 2010). Ontario currently does not have a pre-emptive siting policy for wind farm developments. Using the pre-emptive siting policy, German municipalities were able to define appropriate areas for suitable wind turbine development that would have negligible impacts on the landscape, environment and community areas (Geißler et al., 2013). 
Priority and suitability areas were created to designate land appropriate for proper wind farm development. Priority areas were sites where wind turbines took priority over other types of land uses. Suitability areas were areas where wind turbine development was feasible but prohibited in other areas in a region (Ohl \& Eichhorn, 2010). Suitable areas under the pre-emptive siting policy were chosen by first mapping out all prohibitive criteria such as conservation areas, areas with high sensitivity of landscape scenery, forests and residential areas (Geißler et al., 2013). The second step would be to analyze and designate the wind energy potential of remaining available sites (Geißler et al., 2013). The exclusion criteria may be different from state to state but their principles are generally similar (Geißler et al., 2013). Under these new planning laws, wind farm projects and plans do not include public involvement until the advanced stages since the suitability areas have been already been chosen (Geißler et al., 2013). Although suitability areas are predetermined by the regional planners, the EIA is still required to ensure all impacts have been identified, evaluated, and considered in the decisionmaking process (Geißler et al., 2013).

From a developer's perspective, knowing which areas are suitable for wind farm development is beneficial as this saves time and money during the site selection and permitting process (Geißler et al., 2013). Therefore, proper wind farm placement is essential to receive compensation since a higher rate would be paid for efficient and productive wind farms. A chosen wind turbine type must produce a certain amount of power and the EEG would not pay for wind in poorly planned locations (Ohl \& Eichhorn, 2010).

These new planning amendments created by the German government greatly improved approvals and social acceptance. It is important to note, however, that while this made the approvals process easier, it also reduced the areas suitable for wind turbine developments and caused installation rates to drop (Bruns \& Ohlhorst, 2011). 
Table 3 below shows the decline in rate of installed wind turbine capacity after 1999. These figures include off-shore wind installed capacity.

Table 3: German Installed Wind Capacity and Rate of Change from 1998 to 2012

\begin{tabular}{|c|c|c|c|c|c|c|c|c|c|c|c|c|c|c|c|}
\hline Germany & 1998 & 1999 & 2000 & 2001 & 2002 & 2003 & 2004 & 2005 & 2006 & 2007 & 2008 & 2009 & 2010 & 2011 & 2012 \\
\hline $\begin{array}{l}\text { Installed } \\
\text { Wind } \\
\text { Capacity } \\
\text { (MW) }\end{array}$ & 2,875 & 4,442 & 6,113 & 8,754 & 11,994 & 14,609 & 16,629 & 18,415 & 20,622 & 22,247 & 23,897 & 25,777 & 27,214 & 29,060 & 31,332 \\
\hline $\begin{array}{c}\text { Rate of } \\
\text { Change } \\
(\%)\end{array}$ & - & 55 & 38 & 43 & 37 & 22 & 14 & 11 & 12 & 8 & 7 & 8 & 6 & 8 & 7 \\
\hline
\end{tabular}

(Source: EWEA, 2012)

After the planning laws were implemented, the rate of installed wind capacity drastically increased and began to decrease and stabilize in the last six years. This could be attributed to the reduction of suitable wind turbine areas onshore. Offshore and some onshore wind farm installations may contribute to the steady installation rate anticipated for the next several years.

For comparative reasons, Table 4 illustrates the substantial increase in Ontario's installed wind turbine capacity since 2006, with the exception of 2010. The lack of data is due to the recent transition to renewable energy in Ontario compared to Germany.

Table 4: Ontario Installed Wind Capacity and Rate of Change from 2006 to 2012

\begin{tabular}{|c|c|c|c|c|c|c|c|}
\hline Ontario & 2006 & 2007 & 2008 & 2009 & 2010 & 2011 & 2012 \\
\hline $\begin{array}{c}\text { Installed Wind } \\
\text { Capacity (MW) }\end{array}$ & 395 & 471 & 704 & 1083 & 1184 & 1411 & 2043 \\
\hline $\begin{array}{c}\text { Rate of Change } \\
(\%)\end{array}$ & - & 29 & 49 & 54 & 9 & 19 & 45 \\
\hline
\end{tabular}

(Source: CANWEA, 2013)

It is uncertain and difficult to determine with the limited information available, if the GEA played a part in increasing wind farm developments since the rate of change for wind farm development was high before the GEA was introduced. It is expected that Ontario numbers will drop after new GEA amendments are implemented since they are moving towards the same planning strategy as Germany and offering more rewards for smaller wind farm projects. This should be re-examined over time to 
determine if the GEA has played a large part in wind turbine development. These figures do not include offshore wind development because it is currently not permitted in Ontario. The installed wind turbine capacity may increase if Ontario's imposed offshore wind farm moratorium was lifted. Offshore wind development in Ontario will be further discussed in the Case Study section.

In terms of public acceptance, Germany's renewable energy initiatives have been successfully implemented. In 2009, over 100 German municipalities grouped together to set a community goal of using locally produced renewable energy. The main sources of renewable energy consist of wind, solar, water, and biomass gas. The renewable energy sector has contributed to the local community by creating jobs, creating local income from sold-off energy, and lowering energy costs. With this new energy source, the municipality could eventually become an energy exporter with the goal of creating revenue (Kunze \& Busch, 2011).

Based on Germany's past nuclear history, Germany continues to shift away from nuclear power by phasing out nuclear power plants across the country. The original nuclear phase-out deadline was set at 2036 as proposed by Chancellor Angela Merkel in 2010 (Dempsey \& Ewing, 2011). The German people have been quite passionate in protesting against nuclear power and have urged German politicians to shift away from nuclear power. For example, within weeks after the Fukushima nuclear incident in 2011, approximately 250,000 people across Germany protested against nuclear power (Baetz, 2011). Later in 2011, thousands of German anti-nuclear protestors chained themselves to a railroad to disrupt the transport of nuclear waste from entering the country (Taylor, 2011). Another large anti-nuclear protest, where approximately 120,000 protestors formed a $120 \mathrm{~km}$ long human chain in Hamburg, occurred in the previous year (The Local, 2010). Chancellor Merkel decided to expedite the closure of nuclear power plants to 2022 due to greater pressure from the public (Hall, 2011). 
With the phase out deadline quickly approaching and with $23 \%$ of Germany's current power supply coming from nuclear power plants there is a greater priority for renewable energy development (Hall, 2011). Community support for wind turbine development is an essential factor for success in Germany's thriving wind industry.

In August 2011, the German federal government released the Energy Research Programme designed to promote research and development activities utilized to achieve their policy targets. This program has also resulted in the federal government increasing contributions to research and development budgets from $€ 1.9$ billion between 2006-2009 to $€ 3.5$ billion for the period between 20112014 (IEA, 2013). The next section will discuss Ontario's policy making and planning strategies which created public opposition towards wind farm development.

\section{Ontario History, Policy and Planning}

\section{Ontario Power Generation Past}

In 1906, Adam Beck led Ontario's publicly-owned power project and created a power generation facility in Niagara Falls, Ontario (Ministry of Energy, 2012). Hydroelectric power allowed the citizens of Ontario to have access to electricity. However, after World War II, there was a need for other sources of power to meet the province's electricity demand. Ontario added six coal powered generation facilities in the 1950's to supply areas where demand was highest. Between the 1970s and 1990s, nuclear power was added to supply Ontario's increasing electrical demands (Ministry of Energy, 2012).

In the 1990s, it was recognized that Ontario's power infrastructure was aging and required upgrading and refurbishment. The power system became unreliable and there were concerns of poor planning and mismanagement. By 1999, Ontario Hydro had accumulated a provincial debt of $\$ 38.1$ billion dollars, which accounted for a third of the Province's debt (Trebilcock \& Hrab, 2005). The cause of this debt was primarily the capital costs of construction and expansion of nuclear power plants. 
Mismanagement and inefficiencies during these activities contributed to the cost of power generation expansion. For example, the last of Darlington's units came online in 1993 but was originally scheduled to be fully operational by 1983 . The final cost of the Darlington nuclear power plant was $\$ 14.3$ billion dollars, approximately 3.7 times more than originally budgeted. This resulted in the price of electricity rising $30 \%$ in the early 1990 s (Trebilcock \& Hrab, 2005).

In 1998, Ontario shifted towards an energy market which led to the privatization of generation, planning, and transmission in the energy sector. The intent of privatization was to create more efficient power production but this initiative was short lived. When the market opened in May 2002, the average price of electricity rose approximately $30 \%$ due to increased consumption in the exceptionally warm summer months (Ministry of Energy, 2012). Ontario electricity demands exceeded electricity capacity. In November 2002, the Government of Ontario had to step in and freeze prices. The Government realized there were many issues that needed to be addressed with respect to the increase in demand and lack of supply capacity (Trebilcock \& Hrab, 2005). The blackout in 2003, which occurred in Ontario, reinforced the need to fix the province's electricity policy. As a result, the Ontario government began shifting to energy conservation and utilizing cleaner energy forms (Ministry of Energy, 2012).

In the last ten years, coal power has been gradually phased out of Ontario's power grid. It once provided $27 \%$ of energy to Ontario's power grid, but now only supplies $0.9 \%$ (Ministry of Energy, 2012; IESO, 2014). The Ontario Liberal government decided to replace coal power with renewable energy. Ontario has recently closed eighteen of nineteen coal units and the last unit is planned to be shutdown in mid-2014 (IESO, 2014). The closure of these coal plants has significantly reduced fossil fuel emissions. Coal is a large contributor of sulphur dioxide $\left(\mathrm{SO}_{2}\right)$, nitrogen oxides $\left(\mathrm{NO}_{\mathrm{x}}\right)$, and carbon dioxide $\left(\mathrm{CO}_{2}\right)$ emissions. In $2013, \mathrm{SO}_{2}, \mathrm{NO}_{x}$, and $\mathrm{CO} 2$ emissions were observed to have dropped $93 \%, 90 \%$, and $90 \%$ from 2003 levels, respectively (Ministry of Energy, 2013). 


\section{Renewable Energy Policy}

In 2008 , the Liberal government announced a plan to promote renewable energy development in the Province. The Climate Change Action Plan outlined several steps that would be taken to achieve the goal of reducing greenhouse gas emissions through a shift from coal power generation to renewable energy technology. The Government pledged to reduce greenhouse gas emissions to 6\% below the 1990 emitted levels recorded. They planned to reach targets of $6 \%$ below the 1990 levels by $2014,15 \%$ below by 2020 , and $80 \%$ below by 2050 (Ministry of the Environment, 2010). To achieve the $6 \%$ goal by 2014, the Government planned to shut down all coal power facilities (Ministry of Energy, 2012). The removal of coal power energy is expected to reduce Ontario's carbon footprint by 75\% (Ministry of Environment, 2010).

In the mid-2000s, wind turbine developments were proposed in various communities in Ontario. Wind turbine developers would typically find a suitable site and go through the Environmental Assessment (EA) process for their project to be approved. Typically, the majority of developers would compensate landowners for placing their wind turbine on the landowner's property but no form of compensation would be given to their neighbours (Ontario Sustainable Energy Association, 2005). This type of compensation led to an inequitable benefit distribution since the neighbouring properties received no benefits while being in close proximity to the turbine. This uneven distribution also created a division between neighbours who received no compensation, and landowners who did receive compensation. This led to opposition to the developments in general (Breukers \& Wolsink, 2007).

Community groups were very opposed to wind developments in their community based on the potential negative economic impacts to the community, health impacts, and unwanted visual impacts in their landscapes. Community groups in some areas were able to delay the EA process which forced developers to stop wind turbine projects as they became financially unfeasible projects (Manning \& Vince, 2010). 


\section{Former Environmental Assessment Process for Renewable Energy Projects}

The Environmental Assessment (EA) process was previously used to ensure that all environmental concerns from a proposed development were taken under consideration. Renewable energy developers were also subject to this process. EAs involved many stages of consultation with the public and government agencies.

The initial step in the process requires the developer to create a Terms of Reference ("ToR") document, which is the framework for carrying out the environmental assessment. This document informed the Minister of Environment on how the developer would conduct the environmental assessment with input from environmental studies, construction details, and consultation with the public, aboriginal groups, and government agencies (Ministry of Environment, 2010). After the ToR document is submitted to the MOE, the public, and affected government agencies are given the opportunities to voice concerns and ask questions that the developer must address. The Minister approves the ToR if it is found to be acceptable and the EA can proceed. After the EA is completed and submitted, a second review and comment period is in place for the public and government agencies. The developer is able to make any changes to the EA during this period to address any concerns. The Minister makes the final approval decision after the EA has been submitted.

The EA involves many stages in the approval process since it ensures transparency of the communications between the proponent and the public. This approval process has been an issue for wind developers since there was a lot of time and resources spent in the EA process and there was a high possibility of rejection by government agencies.

\section{Green Energy Act}

In order to improve Ontario's energy situation, the Liberal government introduced a focused energy plan and policy in the early 2000s. One of the goals of this policy was to decommission all coal 
plants within the Province by 2014. Even with the new policy, during the renewable energy transition, wind farm developers found difficulty in the EA process as they still faced heavy public opposition that obstructed their wind farm approvals. The Liberal government responded by creating the GEA to reduce the effects of opposition and expedite wind farm development.

The GEA was passed to improve the EA process since the approval process was too time consuming and costly for the developer. The Ontario Liberal government passed the GEA in May of 2009 and it was enacted in September 2009 (Ministry of Energy and Infrastructure, 2010). The GEA was created to encourage renewable energy development for wind, solar, bioenergy and hydropower (Stokes, 2013). The creation of the GEA has resulted in a strong response for renewable energy applications totalling to over $15,000 \mathrm{MW}$, which is equivalent to approximately $43 \%$ of Ontario's current electricity generating capacity. Of the $15,000 \mathrm{MW}, 69 \%$ was comprised of wind power (Yatchew \& Baziliauskas, 2011).

By creating a streamlined approval process for renewable energy developers, a developer could build renewable energy facilities sooner to provide power to Ontario's power grid. The GEA assists in the government's goal of replacing the energy lost from coal plants being shutdown in 2014 to meet its selfimposed deadline. When the GEA was introduced, Ontario Premier Dalton McGuinty stated that the GEA would prevent the "Not In My Backyard" (NIMBY) mentality that residents and anti-wind groups have often used to impede these projects (Ferguson \& Ferenc, 2009). The GEA was instrumental in subsidizing the capital investment for renewable energy by paying increased rates for renewable power through FIT.

The introduction of the GEA also increased existing tensions between anti-wind groups and government and developers. Wind turbine opposition groups and communities throughout Ontario have 
voiced their frustration with the GEA. These groups stated that the GEA removed their rights and reduced their power to oppose developments in their own communities.

The GEA amended certain sections of the Planning Act (s.62) where it exempted renewable energy projects from Official Plans, zoning by-laws, and development permits. While these exemptions were very effective in encouraging wind farm development, these exemptions also lead to less municipal and local acceptance. Before the GEA, renewable energy projects were subject to the municipality's approval to amend the Official Plan or change the local zoning by-laws. The enactment of the GEA resulted in limited local autonomy by restricting of the municipality's power to approve or reject renewable energy projects within their jurisdiction (Manning and Vince, 2010). This lack of local autonomy reduced municipal involvement and resulted in less municipal commitment and support (Breukers \& Wolsink, 2007). The original EA process gave anti-wind development groups more power to persuade their respective municipalities to reject proposed developments. Municipalities would use the Planning Act as a means to reject wind farm development by stating the project did not conform to their respective current zoning by-laws and/or the municipality's Official Plan. The majority of the community groups' concerns (i.e. detriment to landscape, human health issues, and community economic impacts, etc.) were no longer considered valid under the GEA and it became difficult to reject wind development projects.

Although the GEA was effective in increasing approvals of wind farm developments, there was a loss in local autonomy. This resulted in a further divide between wind farm opponents and proponents. In addition, the GEA made winning the appeals process very challenging for opponents as it required a hearing by the ERT. Any resident in Ontario may appeal a wind farm development but the resident must demonstrate to the ERT that the EPA has been violated for the ERT to consider a hearing. The resident must demonstrate the wind farm project will either cause serious harm to human health or cause 
serious or irreversible harm to plant life, animal life or the natural environment (Walker, 2013). There have been no cases yet in Ontario where the ERT has rejected a wind farm development on grounds of harm to human health. As stated earlier, the ERT has recently rejected a wind farm project in Prince Edward County on the basis that the proposed road leading to the potential wind farm would be detrimental to a population of turtles. Therefore, the developer did not satisfy the ERT by providing a mitigation plan to prevent harm to the turtles (Sahni \& McCutcheon, 2013).

Germany was also faced with problems similar to Ontario with respect to opposition to wind farm developments, but the strategies utilized by Germany lead to a different outcome. Germany's policy making history and planning strategy will be examined in the section below.

\section{Future Policy and Planning Direction}

In late 2012, Dalton McGuinty, the Premier of Ontario, considered to be the figurehead of the GEA, announced his resignation. In early 2013, Kathleen Wynne was selected as the new Premier of Ontario and it was uncertain whether she would revise the GEA developed under the McGuinty government.

In mid-2013, the Wynne government announced several initiatives to revise the renewable energy development process. The FIT program was to be redeveloped and cater to projects less than $500 \mathrm{~kW}$. Renewable energy projects greater than $500 \mathrm{~kW}$ were to undergo another procurement process but the details of this new process have not been released as of writing (Lord, 2013).

Another change to the renewable energy approval process is that the province will work with municipalities to provide them with the power needed to approve renewable energy projects within their jurisdictions. The provincial government anticipated the new process would require developers and renewable energy planners to work with the municipality to select appropriate locations and site requirements for any future renewable energy projects (Government of Ontario, 2013a). These new 
initiatives appear to have been created to promote local acceptance and positive attitudes in current and potential communities involved with renewable energy development.

Both Germany and Ontario experienced energy issues that led to the development of wind farms. These two jurisdictions also encountered the same problems with public opposition. However, this is where the similarities between Germany and Ontario on wind farm development end. A contributing factor that led to Germany's shift to renewable energy is past incidents with nuclear power. Chernobyl and Fukushima have helped improve public acceptance for wind farm development by increasing negative perception of nuclear power.

Both Germany and Ontario faced the same public concerns about health impacts, disruption of natural landscapes and harm to wildlife. The main difference between these two jurisdictions is how Germany effectively dealt with public opposition in comparison to Ontario. The German government worked with municipalities to create pre-emptive siting policies to ensure wind farm development met the federal government's goals. German municipalities were given the ability to select suitable areas and were included in wind farm planning processes. This policy and planning strategy differs from Ontario's since municipalities and residents of Ontario had no input or power in the wind farm approval process under the GEA. This lack of ability to participate and local autonomy generated public opposition to wind farm development. The Scarborough Bluffs case study showcases this problem.

German policy making and planning strategy worked well to gain public acceptance, but these are not the only strategies used. The next section will discuss effective strategies used to create appropriate incentives to encourage public acceptance of wind farm development. 


\section{Incentives}

Incentives have been used as a method to increase positive attitudes and acceptance of wind farm developments in both Ontario and Germany. Co-operative agreements would be considered an incentive since both producers and communities would benefit in the arrangement. A comparison of the incentives used by each of these governments will be discussed to determine which incentives have been effective, ineffective, or require improvement. The main types of incentives to be discussed will be economic, environmental, health, and community.

\section{Environment}

Climate change is a direct result of the greenhouse gas emissions that have increased unchecked. The environmental incentive of using a renewable energy source is that there is a reduction of $\mathrm{SO}_{2}, \mathrm{NO}_{x}$, and, $\mathrm{CO}_{2}$ emissions into the atmosphere. The emissions of these gases come primarily from use of fossil fuels such as coal and oil.

In the last two decades, Germany has been able to reduce greenhouse gas emissions (GHG) and continued to grow economically while remaining able to meet its Kyoto Protocol targets. Germany has committed to a GHG reduction target of $40 \%$ below the 1990 levels by 2020 and set additional reduction targets of $55 \%$ by $2030,70 \%$ by 2040 and $80 \%$ to $95 \%$ by 2050 , each relative to 1990 levels (IEA, 2013).

According to the German Federal Ministry for the Environment, Nature Conservation and Nuclear Safety, approximately 146 million tonnes of $\mathrm{CO}_{2}$ were avoided through the use of renewable sources in 2012. Electricity from renewable sources accounted for a reduction of 101 million tonnes while heat from renewable energy sources accounted for a reduction of approximately 40 million tonnes of $\mathrm{CO}_{2}$ equivalents. 
The Ontario government stated that, as of 2011, coal power generation reached a 48-year low and $\mathrm{CO}_{2}$ emissions produced by coal power had been reduced nearly 90\% between 2003 and 2011 (Government of Ontario, 2012).

The advantage of wind energy is that it produces virtually no emissions during turbine operation and produces very little during the manufacturing, installation, and maintenance process (EWEA, 2012). The European Wind Energy Association estimates that by 2020, Europe will have an annual savings of 215 million tonnes of $\mathrm{CO}_{2}$, annual savings of 261,000 tonnes of $\mathrm{SO}_{2}$, and an annual savings of 333,000 tonnes of $\mathrm{NO}_{\mathrm{x}}$ compared to the 2003 levels (EWEA, 2012). These environmental benefits result in indirect benefits, such as health improvements and economic cost reductions.

\section{Health}

In the Ontario Medical Association's 2008 study, Illness Cost of Air Pollution, it reported that air pollution is a substantial cost burden to Ontario's health system and to the health of Ontarians. The study found that air pollution was a contributing factor to 9,500 premature deaths in Ontario. It also found that smog was responsible for approximately 16,000 hospital admissions in 2005 (Ministry of Energy, 2012).

In 2004, the Ministry of Energy examined the health and environmental costs that were associated with coal and wind power generation. The Ministry discovered that when health costs were considered, coal power generation costs were 16.4 cents per kilowatt hour compared to 9.4 cents per kilowatt hour for wind power (Green Energy Act Alliance, 2010).

While equivalent German health studies were not found, these health benefits could be inferred to be the same as Ontario's in terms of reducing pollutants in the environment. This reduction of pollutants would lead to fewer people being hospitalized for respiratory issues related to poor air quality. Germany is currently constructing coal plants to compensate for the loss of energy as nuclear 
power plants are decommissioned. It may seem that the introduction of coal plants appears to counter the health or environmental effects since fossil fuel emissions are released into the environment. The new coal plants built in Germany are considered the most efficient coal plants in the world, and hold an efficiency rating of $46 \%$ while the industry average is $35 \%-38 \%$. When comparing the most efficient coal plant with the industry average, this efficiency rating translates to the same amount of electricity generated while requiring $20 \%$ less coal and the result is a reduction of $\mathrm{CO}_{2}$ emissions by an annual 2.5 million metric tonnes (Franke, 2013).

\section{Economy}

Germany

In 2007, German renewable energy companies earned nearly $€ 25$ billion in revenue and employed close to 250,000 individuals. Approximately $38 \%(94,000)$ of these jobs were directly related to the German wind industry (Scheid, 2009). During the fragile economic climate in Europe during 2009, Germany continued to invest approximately $€ 20$ billion in renewable energy developments. These renewable energy investments stabilized Germany's economy by maintaining and creating jobs (Anonymous, 2009).

Fossil fuel industries such as coal, have been considered in the transition as Germany moves towards a low carbon economy. Figure 1 below illustrates a comparison of the number of jobs created in the coal/conventional fuel industry and the renewable energy industry from 2005 to 2011. 
Renewables create more jobs than conventional energy does Employment in Germany in renewable and conventional energy sectors, 2005-2011 Source: BMU, BMWT

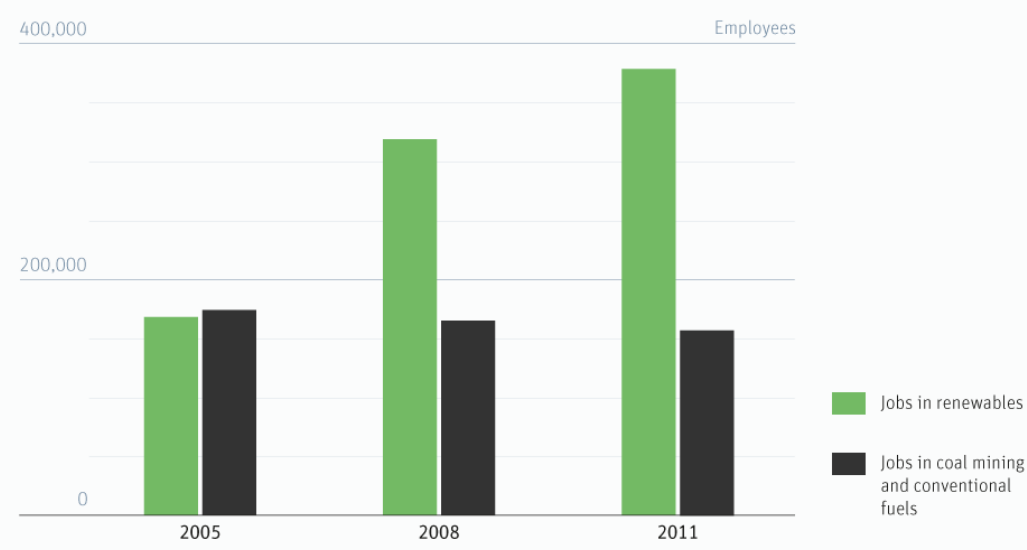

German Energy Transition

Figure 1: Renewable Create More Jobs than Conventional Energy Does

Source: (Energy Transition, 2013)

According to Figure 1 as of 2011 in Germany, there are approximately 380,000 jobs in the renewable energy sector. The types of jobs include roles in manufacturing, installation, and maintenance. The steady increase in jobs in the renewable energy sector is quite remarkable considering other European countries have faced economic strain during this time period.

\section{Ontario}

The manufacturing sector in Ontario has declined in recent years. The Ontario government believes that a shift in the manufacturing sector towards green energy jobs will revitalize Ontario's economy. It is estimated that 50,000 new direct and indirect jobs will be created through the GEA (Ministry of Energy, 2011). In 2010, Samsung, Siemens, and Canadian Solar Inc., announced the creation of solar panel and wind turbine blade manufacturing facilities in Ontario. Approximately 1,400 manufacturing jobs will be created to help establish the renewable energy sector in Ontario (Ministry of Energy, 2011). 
As of May 2013, there have been approximately 31,000 jobs created through the GEA. The majority of these jobs are in the manufacturing sector and did not exist five years ago (McEachern \& Stevens, 2013). According to the Canadian Wind Energy Agency, Ontario is projected to install more than $5,600 \mathrm{MW}$ of wind energy capacity by 2018 , resulting in the contribution of more than $\$ 1.1$ billion of revenue to municipalities across the province (CANWEA, 2013).

In addition, research and development is a becoming a highly-competitive area in this sector. According to the Ministry of Research and Innovation, there are twelve research institutions across Ontario dedicated to alternative energy research and development. In 2005, the Ontario Centre of Excellence for Energy was created to expedite research findings in the marketplace by creating partnerships between academic researchers and private sector companies (Ministry of Research and Innovation, 2013).

\section{Community}

\section{Germany}

For the purpose of this study, community incentives are direct community benefits resulting from wind farm or renewable energy development, and are in the form of reduced community service costs (i.e. taxes, fees, etc.) or increase of services (i.e. new infrastructure, community programs, etc.).

In Germany, there are various types of owners of renewable energy facilities. Figure 2 below shows over half of the installed renewable energy is owned at the community level by private individuals and farmers. Local ownership leads to greater support for wind farms since the community has a vested interest and is more likely to be part of the decision-making process to ensure wind farm developments succeed (Breukers and Wolsink, 2007). 
There is a significant contrast with Ontario where compensation is only provided to landowners by developers and the neighbouring properties receive no incentives and benefits despite the perceived impacts to their well-being and property value. This creates a polarizing situation where, because neighbouring residents are not compensated, they are generally opposed to the project.

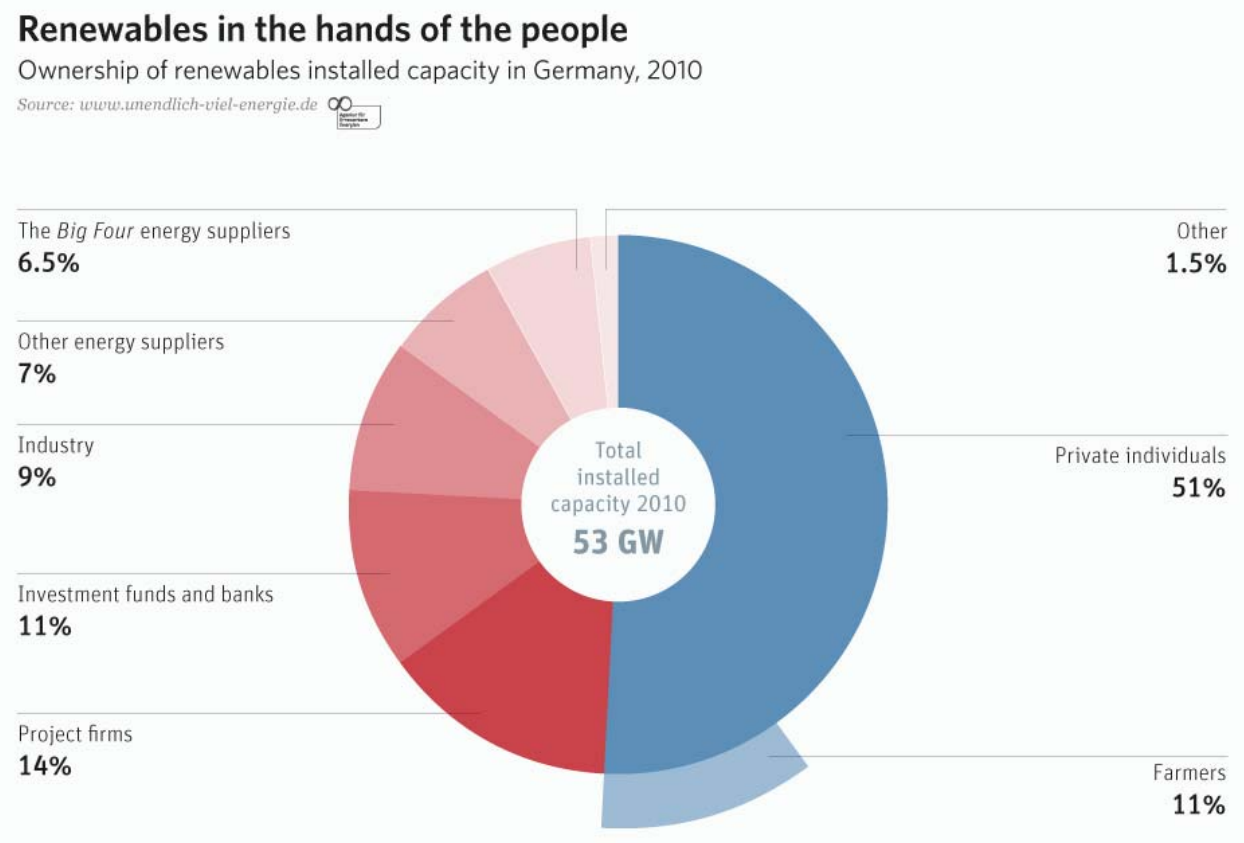

German Energy Transition energytransition.de (C) Ex sa

Figure 2: Renewables in the Hands of the People

Source: Energy Transition, 2013

Communities in Germany realize the importance of renewable energy and have been willing to become involved in the renewable energy planning process. The combination of incentives and public inclusiveness of wind farm planning has allowed successful implementation of wind farms in Germany. For example, the city of Zschadraß's movement towards renewable energy was primarily a financial decision. Approximately a decade ago, the city realized that energy costs were one of the largest contributors to the city's community expenses. The mayor proposed the idea of the construction of a 
$\mathrm{CO}_{2}$ neutral community gym after the first gym was destroyed by a flood. The $33 \%$ energy savings from this new gym helped reduce rent for the local clubs that use the gym (Musall \& Kuik, 2011).

Theökologisch-soziale Bürgerstiftung, Ecological-Social Citizens Foundation (ESCF), was created by Zschadraß's residents and acts as a committee to make environmental decisions to improve the community. The ESCF invested in solar photo-voltaic installations in community buildings. The $€ 17,000$ in profits generated from selling the extra power to the grid were used to support community projects such as providing a school lunch allowance for students who come from low-income families (Musall \& Kuik, 2011).

In 2008, the local power company was aware of Zschadraß's renewable energy projects and asked if the town would be interested in having some wind turbines installed in their community. The community agreed and the ESCF acted as the community liaison for the project. The power company and community financed the project together, which was worth $€ 3.2$ million. This partnership enabled Zschadraß residents to have co-ownership of wind turbines where $20 \%$ belongs to the community and $80 \%$ belongs to the power company. Although $20 \%$ ownership does not seem a sizable amount, this percentage amounts to $€ 640,000$ annually for the small community of 3,079 residents. Zschadraß is now $100 \%$ self-sufficient in local electricity from renewable power sources. The four wind turbines were completed and operational in 2009 (Musall \& Kuik, 2011). It is important to note that the community gradually added other sources of renewable energy instead of relying on only wind energy. This provided the community with the comfort of reliable renewable energy and the positive incentives associated with it.

\section{Ontario}

As stated earlier, the common owner for wind farms in Ontario is the wind developer, who has a direct compensation arrangement with the landowner. The typical agreement establishes a set amount 
of compensation for the landowner in return for providing the land where the wind turbine would be situated.

The Wolfe Island wind farm is located on Wolfe Island, Ontario, near Kingston. This 197.8 MW wind farm began operation in mid-2009 and consists of 86 wind turbines. The Wolfe Island wind farm developers, TransAlta, and the Township of Frontenac Islands have an agreement where the Township would be compensated at least $\$ 649,000$ plus a percentage of revenue each year for 40 years (Frontenac Islands, 2006). This money would be used to improve the community in the form of road construction, beach-bike paths, and new water treatment systems (Laing, 2013). It is unknown if there is an arrangement for private landowners.

There has been very limited literature pertaining to community incentives in Ontario. The fact that there are no community owned wind farm developments in Ontario could be a contributing factor to the negative attitudes and perceptions of wind farms in the rural areas where the majority of wind farms are typically situated.

\section{Infrastructure and Feed-In-Tariffs (FITs)}

There is currently a considerable focus on and attention to wind farm development and generation. It is important not only to look at development of wind farms, but at infrastructure and FITs. Well planned and efficient energy infrastructure is essential to provide energy supply to the domestic market and potentially future foreign markets. FITs is a mechanism used to rapidly develop renewable energy production and provide funding for infrastructure.

The grid serves as an essential factor in wind power development. The grid delivers power from the turbines directly to consumers. Therefore, the investment in transmission infrastructure and network distribution for wind energy is essential to efficiently move energy through the grid to areas which require this energy. Wind farms may be disconnected from the grid during high wind events due 
to excess supply to the grid and no capacity to harvest the excess power (Rajpurohit et al., 2008). The projected share of renewable energy generation in the EU is expected to triple from current numbers by 2030 (Schroeder et al., 2013). For this reason it is imperative to investigate various infrastructure approaches for all jurisdictions. Infrastructure strategies in terms of investment and taxes from Germany and Ontario will also be examined.

This section examines policy differences between Germany and Ontario regarding infrastructure and the effects it has on public acceptance or opposition. There are several factors that play a role in providing proper energy infrastructure to the consumer. Decision makers must determine which wind farm locations are optimal to provide stable energy production while also optimizing connection costs to the grid. In addition, there are costs in connecting to and maintaining the grid which need to be accounted for. These costs are passed onto the consumer which can lead to public opposition as energy costs increase for individuals. As stated in the Methodology section, the FIT for each jurisdiction will focus on determining each jurisdiction's strategy and their effectiveness. Also, how each FIT influences public acceptance will be discussed.

\section{Infrastructure - Germany}

Although Germany is many years ahead of Ontario with respect to wind farm development, Germany requires continuous investment in and development of the transmission of energy and infrastructure to support it. As stated earlier, Germany has invested approximately $€ 20$ billion in renewable energy installations. The power generated is useless unless there is a system to effectively and reliably distribute it. Germany employs a FIT system to help developers to build, upgrade, and maintain their infrastructure and wind turbines. German consumers have known for many years that the cost of electricity is higher due to the use of renewable energy. Although the FIT program is successful in financing maintenance of renewable energy systems, German consumers are absorbing the majority of 
the costs which has started to become a burden. This has recently caused political debate in Germany and has led to re-examination of the Energiewende (IEA, 2013).

The bottlenecks in these energy systems are the storage of renewable energy and its transport. Getting the wind energy harvested from the northern coasts to factories and cities in the south requires large scale "power superhighways" as the Germans call them. These routes must cross the boundaries of Germany's 16 states, and be part of one integrated system. This integration is what is missing in Germany's Energiewende. Another problem Germany is encountering with respect to the super highway is varying support from different states. Some states, such as Thuringia, don't like new cables going through their woods, whereas others, such as Schleswig-Holstein, are making plans to become exporters of wind energy, and other states, such as Bavaria, would prefer to be self-sufficient (Economist, 2013).

In 2012, the Energiewende was revised to improve approximately 2,900 km of existing transmission lines and build 2,800 km of new power lines to support this infrastructure demand (Carrera, 2013). The estimated cost to complete the transmission line upgrade is $€ 20$ billion to $€ 30$ billion in the next ten years. These costs do not include upgrades to Germany's 870 distribution systems, as renewable energy is provided to consumers through a distribution system rather than a transmission system (Carrera, 2013). The cost of the distribution upgrade is expected to be between $€ 27.5$ billion to $€ 42.5$ billion (Carrera, 2013). It appears that Germany has started to focus its attention on both the transmission and distribution networks.

The German government is also transitioning to a Smart Grid system. A Smart Grid system is an advanced communication and control technology that manages the electrical grid. This system allows greater flexibility and reliability by reducing service disruptions, and it has the management means to incorporate renewable energy into the electrical grid. The purpose of these Smart Grids is to assist 
consumers' energy conservation efforts, energy management costs, and integrate new technologies such as electric vehicle charging stations (Government of Ontario, 2013b).

A Smart Grid can coordinate and distribute large power quantities from small power producers leading to greater efficiencies from a management perspective. This will help improve grid automation with real-time management for greater energy savings, reduce the cost of power over time, and increase reliability from new sources of renewable energy (Ministry of Energy, 2013). As time passes and infrastructure improves, renewable energy will be efficiently managed throughout the country.

\section{Infrastructure - Ontario}

Ontario is in a similar situation to Germany in terms of infrastructure development and Smart Grids implementation. The lack of investment in Ontario's energy infrastructure between 1995 and 2003 has set Ontario back in terms of reliability of supply in satisfying its electricity needs. Since 2003, the Ontario government has invested over $\$ 7$ billion to upgrade more than 5,000 km of transmission wires. There continue to be plans drafted to increase transmission and infrastructure projects which would allow more development of renewable energy (Ministry of Energy, 2013).

Ontario is set to invest approximately $\$ 2$ billion over the next seven years to ensure the various renewable energy sources can be reliably transmitted throughout Ontario. This investment is essential since it is forecasted that approximately 4,000 MW of renewable energy will be incorporated into Ontario's power grid in that time (Ministry of Energy, 2013).

Ontario is planning to raise electricity prices to help fund transmission and infrastructure upgrades. For example, it is projected that the industrial rate will increase by $2.7 \%$ over the next 20 years. Also, the residential electricity prices are expected to rise to approximately $7.9 \%$ annually (or $46 \%$ over five years) (Ministry of Energy, 2013). These price increases raise another argument for opponents 
of wind farm development. Critics believe these price increases make wind energy less marketable economically and that development should cease.

Germany and Ontario are quite similar in infrastructure development needs. Both jurisdictions realize the importance of investing in transmission and distribution infrastructure in order to effectively and efficiently maximize renewable energy use. Ontario has recently allocated resources to upgrade its infrastructure. However in the last two years, Germany has decided to invest in further infrastructure up grades even though renewable energy has been used for almost 25 years. This could be a result of the recent developments in SMART grid technology to effectively and efficiently manage and deliver energy from various intermittent renewable energy sources (i.e. wind and solar). Presently, infrastructure does not appear to have any direct influence on public acceptance and opposition in Ontario or Germany.

\section{Feed-In Tariff}

Ontario and Germany have very similar approaches to their FIT programs and their plans for infrastructure improvements. However, there are some differences in the effectiveness of their FIT programs. The goal of a Feed-In-Tariff (FIT) is to stimulate renewable energy development and generate stable incentives for new investments in renewable technology (Mabee, 2012). A benefit of FIT is its effectiveness in reducing costs per kWh as it reduces financial and regulatory risk (Stokes, 2013). A FIT program must meet three criteria: a standard purchasing price per unit of supplied electricity (i.e. $\$ / \mathrm{kWh}$ for Ontario and $€ / \mathrm{kWh}$ for Germany); that electric utility is required to buy all available electricity; and a long-term contract (typically 15-20 years) at a set price must be in place. Ontario and Germany both meet these criteria with their FIT programs (Stokes, 2013).

FIT programs are also used to encourage innovation as they reduce the costs for research and development. FIT costs should decrease with time if the program is properly employed. Another benefit of FIT programs is that they provide investors with certainty and stability, as they decrease volatility in 
energy prices and risk premium when using renewable energy (Stokes, 2013).The FIT program also enables participation from different types of stakeholders since it is not only restricted to large renewable energy developers. FIT allows small-scale and community projects to benefit from renewable energy projects (Mabee, 2012).

A drawback of the FIT program is the challenge for governments of setting the standard price. Initially setting the price too low would lead to tariff increases in the future which would decrease innovation and reduce public support (Stokes, 2013).

\section{Feed-In-Tariff in Germany}

Ontario and Germany's FIT program goals are practically identical. Germany's FIT goals consist of ensuring secured renewable energy investment through guaranteed FIT and providing priority grid connections to ensure prices for every kilowatt generated will be the same for next twenty (20) years. The second goal is to encourage innovation by gradually reducing FIT since this will work to promote competitiveness through technological innovation and research. Another goal is to prevent renewable energy from becoming subsidized through taxes and passing the costs on to consumers (German Renewable Energies Agency Information Platform, 2013). Based on these goals, Germany's FIT program has been an important factor in the country's successful renewable energy development.

FIT provides desirable investment security for small co-op groups, communities, and companies as it leads to locally retained profit. The combination of the FIT program and incentives provided by wind farm development increases public involvement and leads to greater public acceptance of renewable energy sources (Mabee, 2012).

Both jurisdictions' FIT programs possess the same criteria and their goals are similar with respect to infrastructure upgrades, encouraging innovation, meeting environmental goals, generating jobs and providing a guaranteed long term rate for renewable energy projects. This is no surprise as 
Germany was the first country to create the FIT program and Ontario adapted it to help grow their renewable energy portfolio.

\section{Feed-In-Tariff in Ontario}

Ontario's FIT program was created as an investment to retrofit the Province's aging electricity infrastructure, enable the Province to meet their environmental goals, and to create jobs in order to become prosperous (Böhringer et al., 2012). The Ontario government used the FIT program since it was quite effective in increasing capacity quickly. The FIT programs removed barriers and encouraged renewable energy growth as demonstrated in various jurisdictions around the world (i.e. Germany) (Stokes, 2013). Therefore, FIT was an attractive way to expedite the development of renewable energy in order to meet Ontario's 2014 coal power shutdown deadline.

The FIT price schedule was created based on the cost of generating electricity from each source plus a rate of return $10 \%-12 \%$ (as estimated by Ontario Power Authority). In 2009 , the rate under the new FIT program was 13.5 cents/kWh, increased from 11.5 cents/kWh under the original FIT program. This rate increase resulted in an increase in large scale wind farm deployment (Stokes, 2013). The combination of easy wind farm approval processes and favourable rates of return encouraged wind developers to develop throughout the province. Although the Ontario government welcomed this increase in wind farm development, public opposition to wind farm developments arose, as mentioned earlier in the Policy and Incentives section (Stokes, 2013).

As mentioned above, Ontario is currently meeting its FIT goals by upgrading its aging transmission infrastructure to be compatible with the new renewable energy production infrastructure, thereby meeting its environmental goals by shutting down coal plants and creating jobs in renewable energy. However, one of the main criticisms of the Ontario FIT program is the inconsistent political decision making experienced by both wind opponents and proponents. For example, wind farm 
opponents criticized the FIT's price schedule since it was considered too high and resulted in overburdening the consumer. The rate-payer funded FIT program was a large contributor to the recent increases in electricity rates in Ontario. For wind farm proponents, the government's decision to place a moratorium on offshore wind farms resulted in the cancellation of existing contracts, loss of potential revenue, and a decrease in credibility (Stokes, 2013). The offshore wind moratorium will be discussed in further detail in the Case Study section.

Another issue that FIT programs encounter is their transparent nature. This is an issue in the sense that wind farm opponents can compare the cost of renewable energy to conventional energy sources (i.e. natural gas, coal, nuclear etc.), allowing opponents to easily attack renewable energy costs and subsidies while not acknowledging energy subsidies or tax breaks for fossil fuels (Stokes, 2013). For instance, international support for renewable energy included approximately $\$ 88$ billion in subsidies in 2011 while fossil fuel subsidies drew in $\$ 523$ billion, approximately six times more than the former (Stokes, 2013).

It is important to set the correct price rate since, if it is too high, consumers will complain the costs are too great, and if the rate is too low, investment in renewable energy will be negatively impacted (Stokes, 2013). FIT adjustments are common because stability in these systems is often very difficult to achieve. However, Ontario reviewed its FIT system in 2012 and plans to reduce the wind rate from 13.5 cents/kWh to 11.5 cents/kWh (Ontario Power Authority, 2014).This lowers the price compared to Germany, where the current German onshore rate is $0.09 € / \mathrm{kWh}$, which translates to approximately 14 cents/kWh CAD (Renewable International, 2014). These rates are solely given as a general comparison as it is uncertain if these are accurately comparable. As stated in the Methodology section, a price rate analysis is outside the scope of this study. 
Germany and Ontario's FIT programs have similarities, but the implementation of their FIT programs, combined with other factors, including policy decision-making, public participation, and community incentives, has influenced public acceptance and opposition with respect to wind farm development. Ontario's FIT program has the same framework as Germany but public criticism has arisen based on governmental decisions. The Green Energy Act (GEA) and FIT program enabled wind farm development to occur quickly throughout the province in order to satisfy the government's mandate. However, the increase in development caused further tensions between wind farm opponents and proponents. These tensions caused the FIT program and wind farm development to be scrutinized by opposition groups with complaints of high energy bills, harm to human health, endangered wildlife, and devaluation of property. In addition, the government's decision to impose an offshore moratorium demonstrated their indecision and made the whole project and government less credible. These events have led to a lack of trust in the Ontario government's energy policy.

Infrastructure and FIT do not have a direct impact on public acceptance or opposition. However, when these factors are employed in conjunction with other factors such as policies and incentives, public acceptance and opposition to infrastructure and FIT are easily subject to criticism due to their transparent nature.

The next section will examine two case studies one from both Ontario and Germany which demonstrate the effects of factors such as policy making, incentives and public participation, to illustrate each proposal's successes and failures.

\section{Case Study}

The German case study will demonstrate that a transparent process, equal distribution of compensation, and consistent government decision-making influenced public acceptance to wind farm development. 


\section{Germany - Zschadraß and Nossen Case Study}

This German case study highlights the effectiveness of using proper incentives and public inclusiveness during the siting process and can be compared to Ontario's wind farm development situation. The study was conducted to compare two communities in Germany, Zschadraß and Nossen, in order to observe attitudes towards wind turbine development within their respective communities. These towns had different siting approaches and conflict management processes. Zschadraß went through the siting approach typically employed in Germany where incentives and public inclusiveness were included in the siting process. The community of Nossen had an approach similar to the one used in Ontario where the public was excluded from the wind farm development process and incentives were not distributed to the community. For example, Nossen town officials did not consider residents to be stakeholders in the wind farm siting process. There was no community ownership of the wind turbines installed in Nossen and residents were only compensated through a reduction of local taxes and rent (approximately $€ 7,800$ in 2009). This compensation was not used for community funding of projects (Musall \& Kuik, 2011).

To support the study, Musall \& Kuik conducted a survey with 100 residents from both Zschadraß and Nossen to quantify the attitudes towards wind farm development within each respective community. When residents were asked if noise was a disadvantage for wind turbines in Zschadraß only $15 \%$ of residents agreed, while in Nossen $44 \%$ responded that it was. The small number of Zschadraß's respondents noted they were only affected by noise caused by wind turbines during certain weather conditions. The respondents in Zschadraß reported the noise to be as bothersome as other impacts such as landscapes and shadows. These reported impacts were quite bearable and less bothersome. However, Nossen respondents perceived the same impacts as a clear disadvantage for wind turbine development (Musall \& Kuik, 2012). 
The majority of Zschadraß's residents, $80 \%$, believed that Germany should increase wind turbine use while only $36 \%$ agreed in Nossen. Zschadraß residents were asked about their opinion of the local wind turbines, and the results showed $62 \%$ of responses were positive, $36 \%$ were neutral, and $1 \%$ were negative. Nossen had opposite results, $26 \%$ of the responses were positive, $47 \%$ were neutral, and $27 \%$ were negative (Musall \& Kuik, 2012).

Survey participants were asked if there was a relationship between the installations of renewable energy in their community and building a better future for their children. Nossen's respondents were mixed where $30 \%$ agreed with the statement and $25 \%$ were undecided, $37 \%$ disagreed, and $8 \%$ did not know. Zschadraß's attitudes were definitive, $92 \%$ of respondents agreed, $6 \%$ were undecided, and 2\% disagreed (Musall \& Kuik, 2011).

When respondents were asked about perceived transparency in the planning process, $53 \%$ of respondents from Zschadraß believed the planning process was transparent, 37\% did not know, 7\% disagreed, and 3\% were undecided. Only 9\% in Nossen agreed, 46\% disagreed, 38\% did not know, and 7\% were undecided. Researchers believed the reason the response proportion for "did not know" was high was due to the time restrictions (work schedule) respondents had during the planning process (Musall \& Kuik, 2011).

These responses display the contrast between the two communities' perceptions of wind turbines and the siting processes used within their communities. Zschadraß residents were more positive toward wind turbines in their community since they did not experience conflict during the siting process.

The acceptance survey between Zschadraß and Nossen further reinforced the benefits of a cooperative siting process by removing conflict in asking residents about their attitudes and perceptions of wind turbine development and the siting process. Overall, residents of Zschadraß had positive attitudes 
towards the planning process, wind turbine development in Germany, the important role it played in their community, and the future of their children. Negative factors from wind turbine development such as noise, shadow, and detriment to landscape were more bearable and less bothersome to the residents in comparison to residents in Nossen. The responses from Nossen's residents were a complete contrast to Zschadraß. The residents had a lot of distrust of the siting process, negative attitudes for wind turbine development in Germany and they did not believe wind energy would be beneficial to their children. Factors such as noise, shadow, and detriment to landscape were all considered disadvantages of wind turbines.

\section{Ontario - Scarborough Bluffs Offshore Case Study}

In 2006, Toronto Hydro proposed to build thirty (30) wind turbines off-shore along the Scarborough Bluffs in Lake Ontario (Doolittle, 2006). This number increased to sixty (60) wind turbines across a twenty-five (25) kilometer stretch in Lake Ontario spanning from Ajax to the Leslie Street Spit (Spears, 2008).The initial estimated height for these turbines was $100 \mathrm{~m}$ and the wind turbines were planned to be two (2) to four (4) kilometers offshore from the Scarborough Bluffs (Hamilton, 2009). Hydro Toronto projected this distance would be optimal since winds this distance offshore tend to be 70\% stronger (Spears, 2008). In 2010, the Liberal government announced the minimum setback for offshore wind projects to be five (5) km (Marketwire, 2010).

In 2006, Toronto Hydro received approval from the Ministry of Natural Resources to install a weather station that included an anemometer to measure wind speeds $1.2 \mathrm{~km}$ offshore. This weather station would collect data for two years that would be analyzed to determine the suitability of the site (Doolittle, 2006). Wind opposition groups stated this project was poorly planned since the weather station would not provide suitable data to establish the feasibility of this location for offshore wind development along the Scarborough Bluffs (Marketwire, 2010). The poor implementation of the 
weather station gave wind opposition groups the perception that the project was being mismanaged and it reinforced a lack of trust.

Scarborough Bluffs residents and wind farm opposition groups protested the development based on the grounds that it would ruin the visual aesthetic landscape, reduce property value, and harm birds (Hamilton, 2009). In November 2008, approximately one thousand people attended a public information meeting presented by Toronto Hydro to discuss the wind farm project. An earlier meeting was scheduled a month prior, but was cancelled as the venue was over capacity, and an additional two hundred people were not able to attend. This meeting was considered very polarizing since outside environmental groups transported wind energy supporters to the meeting. When outside stakeholders are involved in community decisions, their attitudes, competence and agendas are scrutinized by the affected community as they are not considered to have the same vested interests (Wüstenhagen et al, 2007). This caused Scarborough Bluffs residents to resent the project even more since the residents would be the ones impacted (Spears, 2008). In 2010, two (2) local councillors, Paul Ainslie and Brian Ashton, asked the province to impose a blanket moratorium on wind-power development in Ontario (Paperny, 2010). This demonstrated that the local government officials were against this project and supported their respective constituents.

It is not clear whether residents along the Scarborough Bluffs would have been provided compensation since these wind turbines were only visible in the distance. Assuming the same compensation methods practiced elsewhere in Ontario and mentioned in the above Incentives section, the residents would be considered neighbours and would not receive compensation. The lack of incentives and benefits would be another factor leading to further opposition to the wind project. Residents were opposed since they would be subjected to wind turbines supported by outside interest groups, they would have no ability to reject the project and would not receive compensation. 
The Scarborough Bluffs wind opposition group was relieved in February 2011, when the Liberal government announced an offshore wind project moratorium due to environmental concerns. Energy Minister Brad Duguid explained additional research would be required due to the lack of research on freshwater wind projects while land based wind projects have had extensive research. Wind farm opponents and political opposition groups claimed this move was a politically motivated decision by the Liberals to gain more support from urban areas and areas affected by offshore wind development (Talaga, 2011).

Although the Scarborough Bluffs wind farm project was halted, the sight of the weather station that was still collecting data angered wind farm opponents since it served as a reminder of the proposed wind development project. The local government also attempted to intervene on behalf of the wind farm opponents. Scarborough-East Councillor, Paul Ainslie, who was against the wind farm development, tried unsuccessfully to remove the weather station before its intended data collection end date in August 2012 (Scarborough Mirror, 2013).

Although this wind farm siting process dealt with a proposed offshore wind turbine development which had a greater setback distance than land based wind turbines, there were several similar key issues identified in this case study. This project was initiated by an outside party with interests that were not parallel to those of the community, and the community did not participate in the planning decisions that led to the wind farm development. There was a lack of local resident and government support for this wind farm development project. This created a polarized environment where residents did not trust any external groups who spoke to the community. The implementation of the weather station was an example of poor planning that reinforced the mistrust of the residents. It was also anticipated that residents would not receive any compensation or direct benefits for 
proceeding with this project. All of these factors contributed the resident's opposition to wind development along the Scarborough Bluffs.

\section{Discussion}

Table 5 provides a summary comparison of Ontario and Germany's wind farm development strategies in terms of the four main factors reviewed in this study.

Table 5: Comparative Factors Summary

\begin{tabular}{|c|c|c|}
\hline Factor & Germany & Ontario \\
\hline Policy & $\begin{array}{l}\text { - } \quad \text { Shift away from } \\
\text { nuclear power }\end{array}$ & $\begin{array}{l}\text { - Shift towards low } \\
\text { carbon economy }\end{array}$ \\
\hline Planning & $\begin{array}{ll} & \text { Pre-selected sites } \\
\text { - } & \text { Municipality decides } \\
\text { the pre-selected } \\
\text { sites } \\
\text { - } \\
\text { - } \\
\text { Encounicipal power } \\
\text { participation and } \\
\text { inclusiveness } \\
\end{array}$ & $\begin{array}{ll}\text { - } & \text { Municipal power } \\
\text { - } & \text { Pemoved } \\
& \text { transparency } \\
\text { - } & \text { Lack of public } \\
& \text { participation } \\
\text { - } & \text { Increase in public } \\
& \text { opposition } \\
\end{array}$ \\
\hline Incentives & $\begin{array}{ll} & \text { Co-operative } \\
\text { ownership } \\
\text { - } & \text { Community benefits } \\
\text { - } & \text { Successful in gaining } \\
& \text { public acceptance }\end{array}$ & $\begin{array}{ll}\text { - } & \text { Individual } \\
& \text { landowner } \\
\text { compensation } \\
\text { - Unequal } \\
\text { distribution of } \\
\text { compensation } \\
\text { - Does not resolve } \\
\text { public opposition }\end{array}$ \\
\hline $\begin{array}{l}\text { Infrastructure and } \\
\text { Feed-In-Tariff }\end{array}$ & $\begin{array}{ll}\text { - } & \text { Created FIT model } \\
\text { - } & \text { Ond still using } \\
\text { Ontario's goals and } \\
\text { factors are the same } \\
\text { for Germany } \\
\text { - Investing in } \\
\text { distribution and } \\
\text { transmission } \\
\text { (SMART grid) }\end{array}$ & $\begin{array}{ll}\text { - } & \text { Adapted } \\
\text { - } & \text { Sermany's FIT } \\
\text { factors employed } \\
\text { by Germany } \\
\text { - } \\
\text { Investing in } \\
\text { distribution and } \\
\text { transmission } \\
\text { (SMART grid) }\end{array}$ \\
\hline
\end{tabular}

When examining both Ontario and Germany's renewable energy history, it appears both jurisdictions were quite different but they were similar in some respects. Germany determined renewable energy to 
be an important source of energy since it enabled Germany to be less reliant on foreign energy sources. Ontario switched to renewable energy since there was a supply problem and a demand for renewable energy. Both Germany and Ontario also recognized that renewable energy would be beneficial to the environment and result in the reduction of GHG gas emissions. This was another reason that led to Ontario's pledge to close all coal plants by 2014.

Germany has not shown any sign of slowing down wind farm developments since it utilizes wind power from offshore sources. The limitation in Germany's planning strategy to site wind farm developments only in areas approved by the municipality is that it restricts the number of locations available for onshore wind farms. Ontario, on the other hand, has extensive available land for wind farm development. It also has several large bodies of water that are potential sites for offshore wind farms. An example where politics has affected policy choices and decision-making is the Ontario Liberal government's decision on offshore wind farm development. Early in the mid-2000s when renewable energy initiatives were being explored, the Liberal government initially allowed offshore wind farm developments to be proposed. Many studies were completed and investments made to enable offshore development. However, as the case study revealed, in late 2011, the Ontario government imposed a moratorium on off-shore wind farm development and required proponents to conduct further scientific research. The initial research to assess the potential impacts to wildlife and the physical landscape has provided inconclusive results and the government recommended further research rather than lifting the moratorium (Spears, 2013).

Germany was one of the first countries to pave the way towards large scale renewable energy in terms of research and development, financing, policy development and planning. As stated in the above sections, Germany experienced some growing pains in terms of financing and public acceptance issues. Although Chernobyl played a large role in improving public acceptance of wind farm projects, the key 
lesson learned to gain public acceptance was the collaborative planning effort in increasing public participation and transparency. For example, the village of Feldheim has a high level of public acceptance of wind turbines. A method employed to gain the community's trust was to include local experts in the decision making process. For example in Feldheim, an insurance broker checked the contract for legal details before local residents signed it, the head of the agricultural cooperative monitored the financial gains and losses for the village, and some of the local technicians inquired about the construction methods for and practices used in the project. Each of these local experts presented their opinions about the project, in their respective areas of expertise, to the community. This made the project more transparent and understandable to the community and this resulted in more trust in the development (Kunze \& Busch, 2011). These local experts also acted as representatives of the community and voiced any concerns to the project proponents.

Germany realized there was a balance to be struck between fulfilling wind farm development goals and gaining public acceptance. New policies and laws were developed or amended to satisfy both renewable energy targets and public acceptance.

Ontario, having failed to learn the earlier lessons observable in Germany, started differently compared to Germany but is now beginning to use the same wind farm development strategies. Ontario did not experience a catastrophic event as a trigger to move towards renewable energy. However, the 2003 summer blackout in Ontario served as an alarm that something needed to be done. As renewable energy developments were planned, it became apparent that the existing Environmental Assessment (EA) approval process took too long for wind farm developers. In addition, public opposition influenced municipalities to use their power to reject wind farm development projects. The combination of the 2014 coal plant closure deadline, a lengthy EA approval process, mounting public opposition and the 
power of the municipality, led the provincial government to create the GEA allowing renewable energy projects to be built without these obstacles.

The Ontario GEA and the German energy planning laws both had the same intention to develop renewable energy including large scale wind farms but their approaches were different. The Germany strategy was transparent in its approach, where the government concluded wind farm development was vital to meet the country's future demands, but also included the public to determine where wind farms could be built. The study comparison between Zschadraß and Nossen has shown that public involvement is effective in order to gain public acceptance for wind farms. While the Ontario government also promoted renewable energy development as a viable energy source to meet the province's future energy demands, it created the GEA to combat the "NIMBY-ism" it experienced during the EA process. However, this strategy caused additional tension between the government and wind farm opposition groups. It is only recently that the Ontario government has shifted from a mandated and forceful renewable energy strategy to the strategies used in Germany including public participation. Additional studies are required to determine if these new amendments are effective in changing public acceptance of major wind farm developments or if there are any lasting anti-wind policy effects caused by government decision-making.

The rates of increase of installed wind turbine capacity for Ontario and Germany have been almost similar based on the initial years of wind energy development. Germany's installed wind capacity rate has eventually reached a plateau as time has progressed. Similarly, Ontario's rate of new installed wind capacity may decrease due to new amendments in the GEA that promote smaller wind farm developments and grant municipalities the power to accept or reject wind farm developments. There has been no indication by the Ontario government to pre-emptively create selected wind farm development sites, a planning strategy which has helped German wind farm development. Therefore, 
Ontario wind farm proponents should focus on developing incentives and employing collective decisionbased strategies that were effectively utilized in Germany for wind farm development, since it will be more difficult to obtain approval under the current policy.

In terms of incentives, both Ontario and Germany have shown that renewable energy and wind energy do have positive impacts on the environment and their own economies. These incentives will reinforce the actions of these two jurisdictions to continue with wind farm development. The crucial differences between the two jurisdictions are the types of community incentives.

As mentioned earlier, ownership in the wind farm plays a key factor in providing community incentives since it ultimately determines which stakeholders receive compensation. Ontario wind developers typically deal directly with the landowner who would receive the majority of the revenue. This predictably causes tension in and resentment by adjacent property owners resulting in opposition to wind farm development. German community ownership of wind farm developments varies from private citizen groups, towns, and farmers to big energy companies, industry and banks. For example, developers who have provided the community with access to shares have not only created a financial incentive to support development but have also allowed participation and have given direct incentives to the community (Jobert et al, 2007). Research has shown that there is an enhanced level of local acceptance of wind farm development when there is community involvement, collective decisionmaking and compensation involved (Breukers \& Wolsink, 2007). The community has a vested interest to ensure the wind farm development succeeds due to the collective benefits gained. However, in Ontario, the neighbouring residents receiving no compensation do not care if the wind farm development succeeds or fails since they have no incentives.

Both Germany and Ontario have committed to invest billions of euros or dollars in transmission infrastructure and distribution networks in order to efficiently manage power supply and to meet 
energy demands. Germany is currently facing power management issues and it appears energy created from wind farms has outpaced the capacity for transmission and distribution networks. It is unclear if Ontario has learned a comprehensive policy lesson from other jurisdictions on the development of renewable energy sources, the importance of collaborative energy management or if it has learned from the 2003 summer blackout about the importance of investing in energy infrastructure.

The earlier mentioned policies, planning strategies and incentives have influenced the FIT programs for each of these jurisdictions. Although FIT programs themselves do not have a direct impact on public acceptance or opposition, FIT programs are easily criticized due to poor implementation of policies and incentives, public acceptance and opposition to infrastructure as revealed in Ontario. Therefore it is essential for policies, planning strategies, community incentives and public participation to be included in the siting process to ensure public acceptance of wind farm development will be achieved.

\section{Limitations}

There were several limitations in this study. Due to Ontario's recent transition to renewable energy, there was limited access to all of the relevant academic publications and case studies about wind farm development and perceptions in the province. There was also the lack of community owned wind farms to determine how effective they would be in improving public acceptance in Ontario.

\section{Further Studies}

Ontario is moving to a low carbon economy since renewable sources and nuclear power releases virtually no carbon emissions. However, there are some negative connotations associated with nuclear power such as the potential for major catastrophic events caused by nuclear meltdowns or the radioactive waste created from the nuclear power process. 
Further research should be conducted to determine if Ontario's nuclear power program will have any influence on Ontario's renewable energy development or if nuclear power will act as a hindrance to wind farm development and growth. Ontario currently relies on nuclear energy as a noncarbon emission source and the 2010 Long Term Energy Plan does not include any plans to decommission any nuclear power plants. Ontario has recently committed to refurbishing several of its nuclear power plants and the refurbishment of the Darlington nuclear power plant reinforces Ontario's decision to continue to use nuclear energy to power the province.

Another factor to consider is the energy source differences between Ontario and Germany. As previously stated, coal energy in Ontario has been reduced to provide less than $5 \%$ of Ontario's energy production. Now that Ontario has met its intended goal, this may explain why Ontario has amended the GEA from an aggressive renewable development strategy to a controlled transparent renewable energy process.

\section{Conclusions}

Germany has demonstrated that successful wind farm development requires effective government policy, planning strategies, community incentives, investment in infrastructure and a clearly defined FIT program. While Ontario has the same goal of developing renewable energy within its jurisdiction, it has demonstrated that it has not been as effective in managing public acceptance compared to its German counterpart.

\section{Policy and Planning}

German renewable energy policy was greatly influenced by certain historical events such as the oil energy crisis in the 1970s. However, one of the most influential factors which strengthened German renewable energy policy making and public acceptance was the Chernobyl nuclear incident. Renewable energy funding was planned to be cutback and public opposition of nuclear power was evenly divided 
before the Chernobyl nuclear incident. Due to the devastating effects, impacts and close proximity of Chernobyl to Germany, public opposition to nuclear power grew to $70 \%$ and this helped drive Germany to renewable energy development. Ontario never experienced any nuclear catastrophes and was too far away to experience the impacts from Chernobyl to trigger a strong response from the public to create policies to transition to a renewable energy economy.

German planning strategies worked quite well to gain public acceptance. The main difference between these two jurisdictions was that Germany was able to effectively manage public opposition whereas in comparison to Ontario public opposition played a major role in curtailing wind power development. The German government worked with municipalities to create pre-emptive siting policies to ensure wind farm developments that were needed to meet the country's renewable energy and environmental goals were available. German municipalities were given the ability to select suitability areas that were to be included in the wind farm planning process. This policy and planning strategy is quite different compared to those in Ontario since municipalities and residents under the GEA had no input in to or power to affect the wind farm approval process. This lack of local autonomy and community participation generated public opposition to wind farm development.

The Ontario government is beginning to show signs of transitioning from an aggressive wind farm developing government to a government willing to cooperate with the municipalities and communities through its amendments to the GEA. The Liberal government may have realized it would be beneficial to rebuild relationships with the communities that were subjected to wind farms in order to increase wind farm acceptance for future potential communities. The original GEA approvals process allowed wind farm developers to receive approvals without experiencing any public opposition and conflict. This original policy, which has been imposed for the past five years, has created a large divide 
between Ontario communities and the government. It may take time for communities to regain trust in the government and change their attitudes to wind farm development in Ontario.

\section{Incentives}

Community incentives are effective in gaining public acceptance for wind farm development. Community incentives provide the opportunity for community ownership, an important factor, since the benefits are distributed throughout the community which leads to acceptance and approval for wind farm development. Community members are more involved and feel that they have a vested interest to ensure the project succeeds. The case study of Zschadraß and Nossen demonstrated local acceptance of wind farm development when there was community involvement, collective decision-making and distributed benefits for the whole community. These incentives led to positive experiences and attitudes and resulted in other communities wanting to join in wind farm developments. As stated earlier, over 100 German municipalities set community goals to use more locally produced renewable energy. In order for these goals to be successful, it is essential for these municipalities to use the community based approach to avoid the problems encountered in Nossen. This approach is effective for siting and gaining public acceptance since it incorporates a proactive process in managing and preventing conflict.

In Ontario, wind developers typically interact directly with landowners who in turn receive compensation. The result of this unequal distribution increases opposition since there is tension and resentment from adjacent property owners. Further re-examination and amendments to the GEA to address community distribution of benefits would provide more incentives for communities to accept wind farm developments. The next priority for Ontario and wind farm developers is to create better and more direct incentives for wind farm communities as demonstrated by their German counterpart. 


\section{Infrastructure \& Feed-In-Tariff}

In terms of infrastructure, both Germany and Ontario had the same goals to invest and upgrade their existing transmission and distribution infrastructure. Germany and Ontario's FIT programs had similar goals regarding innovation promotion, infrastructure upgrades, job creation, meeting environmental goals and providing a guaranteed long term rate for renewable energy projects. The FIT programs have been successful in developing wind energy within their respective jurisdictions. However, it is important to note that policy, planning, and community incentive factors must cater to the public's needs since they are vital in the successful implementation of FIT programs.

As provinces in Canada begin to adopt wind energy developments as elements in their renewable energy policies, effective and ineffective strategies employed by Ontario and Germany could serve as a template for other Canadian jurisdictions to learn lessons from these experiences to improve their own wind farm development processes, gain public acceptance and mitigate opposition. Ontario's wind farm development future remains uncertain since its past strategies may have created permanent negative attitudes, and since it is uncertain whether current or future strategies will redeem the public's trust in wind farm development. 


\section{References}

Albadi, M.H., and E.F. El-Saadany. "The Role of Taxation Policy and Incentives in Wind-based Distributed Generation Projects Viability: Ontario Case Study." Renewable Energy 34.10 (2009): 2224-233. Print.

Anonymous. 2009. "Germany at the Crossroads." Power Engineering International 108th ser. 17.5 (2009): 110-11. Web. 7 Apr. 2013.

Anonymous. 2010. Guildwood community calls on toronto hydro to kill wind turbine project off scarborough bluffs. 2010. Marketwire. Retrieved from http://ezproxy.lib.ryerson.ca/login?url=http://search.proquest.com/docview/521456281?accountid=13 631

Baetz, Juergen. 2011. "Germany Nuclear Power Protest Draws 200,000." The Huffington Post. TheHuffingtonPost.com, 26 Mar. 2011. Web. 23 June 2014.

Bechberger, Mischa, and Danyel Reiche. 2004. "Renewable Energy Policy in Germany: Pioneering and Exemplary Regulations." Energy for Sustainable Development 3.1 (2004): 47-57. Print.

Blackwell, Richard. 2012."N.S. Aims for Big Results From Small Power Projects." Energy \& Resources. The Globe and Mail, 29 Jan. 2012. Web. 07 Apr. 2013.

Böhringer, Christoph, Nicholas J. Rivers, Thomas F. Rutherford, and Randall Wigle. 2012. "Green Jobs and Renewable Electricity Policies: Employment Impacts of Ontario's Feed-in Tariff." The B.E Journal of Economic Analysis \& Policy 25th ser. 12.1 (2012): n. pag. Print.

Blok, K. 2013. "Renewable Energy Policies in the European Union." Energy Policy 34.3 (2006): 251-55. Print.

Brachvogel, Frank. 2013."Müller: 2013 Is an Important Year for the German Energy Policy." BDEW RSS. German Association of Energy and Water Industries, 10 Jan. 2013. Web. 25 Aug. 2013.

<http://www.bdew.de/internet.nsf/id/20130110-pi-mueller-2013-is-an-important-year-for-the-germanenergy-policy-en?open>.

Breukers, Sylvia and Maarten Wolsink. 2007. "Wind Power Implementation in Changing Institutional Landscapes: An International Comparison." Energy Policy 35.5 (2007): 2737-750. Print.

Bruns, Elke, and Dörte Ohlhorst. 2011. "Wind Power Generation in Germany - a Transdisciplinary View on the Innovation Biography." The Journal of Transdisciplinary Environmental Studies 10.1 (2011): 45-67. Print.

Büsgen, Uwe, and Wolfhart Dürrschmidt. 2009. "The Expansion of Electricity Generation from Renewable Energies in GermanyA Review Based on the Renewable Energy Sources Act Progress Report 2007 and the New German Feed-in Legislation." Energy Policy 37.7 (2009): 2536-545. Print.

Butler, L., and K. Neuhoff. 2008. "Comparison of Feed-in Tariff, Quota and Auction Mechanisms to Support Wind Power Development." Renewable Energy 33 (2008): 1854-867. Print. 
Canadian Wind Energy Association. 2013. "Wind by the Numbers: Economic Benefits of Wind Energy." Canadian Wind Energy Agency, Jan. 2013. Web. 14 Aug. 2013. <http://www.canwea.ca/pdf/canweafactsheet-economic-web-final.pdf>.

Carrera, Alexandra. 2013. "Germany's Renewable Energy Push: A Promising or Poorly Planned Initiative?" Power Technology. Power Technology, 26 Sept. 2013. Web. 3 Oct. 2013.

$<$ http://www.power-technology.com/features/feature-germany-renewable-energy-promising-poorlyplanned-initiative/>.

CBC. 2012. "Wind Farm Opponents Cheer Federal Study of Health Effects. 2014." CBCnews. CBC/Radio Canada, 11 Jan. 2012. Web. 29 Jan. 2014. <http://www.cbc.ca/news/politics/wind-farm-opponentscheer-federal-study-of-health-effects-1.1161838>.

Chief Medical Officer of Health. 2010. The Potential Health Impact of Wind Turbines. Publication no. 014894. N.p.: Queen's Printer for Ontario, 2010. Print.

Delmas, M. and Montes-Sancho, M. 2011. US State Policies for Renewable Energy: Context and Effectiveness. Energy Policy. 39(5): 2273-2288.

Dempsey, Judy, and Jack Ewing. 2011. "Germany, in Reversal, Will Close Nuclear Plants by 2022."Nytimes.com. New York Times, 30 May 2011. Web. 3 Feb. 2014.

<http://www.nytimes.com/2011/05/31/world/europe/31germany.html?_r=0>.

Diaz-Gonzalez, Francisco, Andreas Sumper, Oriol Gomis-Bellmunt, and Roberto Villafafila-Robles. 2012. "A Review of Energy Storage Technologies for Wind Power Applications." Renewable and Sustainable Energy Reviews 16 (2012): 2154-171. Print.

Doolittle, R. 2006. Wind farm plan has scarborough residents in a huff: National Post. (2006, Jan 11) Retrieved from http://ezproxy.lib.ryerson.ca/login?url=http://search.proquest.com/docview/330493285?accountid=13 631

Dong, C.G. 2012. "Feed-in Tariff vs. Renewable Portfolio Standard: An Empirical Test of Their Relative Effectiveness in Promoting Wind Capacity Development." Energy Policy 42 (2012): 476-85. Print.

Drechsler, Martin, Jurgen Meyerhoff, and Cornelia Ohl. 2012. "The Effect of Feed-In Tariffs on the Production Cost and the Landscape Externalities of Wind Power Generation in West Saxony, Germany." Energy Policy 48 (2012): 730-36. Print.

Energy Transition. 2013. "German Energy Transition - Arguments for a Renewable Energy Future." German Energy Transition, n.d. Web. 2 Oct. 2013. <http://energytransition.de/2012/10/key-findings/>.

Environmental Review Tribunal. "Environment and Land Tribunals Ontario. 2013. " Environmental Review Tribunal. Environmental Review Tribunal, n.d. Web. 6 June 2013.

<http://www.ert.gov.on.ca/english/about/ert/index.htm>. 
Fairley, Peter. 2008. "Can Wind Energy Continue Double-Digit Growth?" IEEE Spectrum 45.2 (2008): 16. Print.

Federal Ministry for the Environment, Nature Conservation and Nuclear Safety (BMU). 2012.

"Renewable Energy Sources 2012." Federal Ministry for the Environment, Nature Conservation and Nuclear Safety, 28 Feb. 2013. Web. 15 Sept. 2013. <http://www.erneuerbare-

energien.de/fileadmin/Daten_EE/Dokumente_PDFs_hgp_2013_ei100179c-13e_zsw_final_bf.pdf>.

Ferguson, Rob, and Leslie Ferenc. 2009. "McGuinty Vows to Stop Wind-farm NIMBYs | Toronto Star." Thestar.com. Toronto Star, 11 Feb. 2009. Web. 15 Mar. 2011.

Franke, Andreas. 2013. "ANALYSIS: German 4 GW New Coal Plants in Testing after First Fire."News and Headlines. Platts, 9 Aug. 2013. Web. 01 Feb. 2014. <http://www.platts.com/latest-

news/coal/london/analysis-german-4-gw-new-coal-plants-in-testing-26170384>.

Geißler, Gesa, Johann Köppel, and Pamela Gunther. 2013."Wind Energy and Environmental Assessments E A Hard Look at Two Forerunners' Approaches: Germany and the United States." Renewable Energy 51 (2013): 71-78. Print.

German Renewable Energies Agency. 2013. "The German Renewable Energy Sources Act - a Story of Sucess." Information Platform. German Renewable Energies Agency, n.d. Web. 3 Sept. 2013. $<$ http://www.unendlich-viel-energie.de/en/policy/the-renewable-sources-act.ht>.

Germany. 2010. Renewable Energy Sources Act of 25 Octover 2008 as Last Amended by the Act 11 August 2010. By Federal Law Gazette. Vol. 1. 2010. Print.

Global Wind Energy Council. 2013. "Global Installed Wind Power Capacity (MW) - Regional Distribution." Global Wind Statistics. N.p., n.d. Web. 22 Aug. 2013. <http://www.gwec.net/wpcontent/uploads/2012/06/Global-installed-wind-power-capacity-MW-\%C3\%94\%C3\%87\%C3\%B4Regional-Distribution.jpg>.

Goverment of Ontario. 2012. "Climate Vision: Climate Change Progress Report." Government of Ontario, 13 Nov. 2012. Web. 23 Oct. 2013.

<http://www.ene.gov.on.ca/stdprodconsume/groups/Ir/@ene/@resources/documents/resource/stdpr od_101103.pdf >.

Goverment of Ontario. 2013a. "Ontario Working With Communities to Secure Clean Energy Future."Newsroom :. Government of Ontario, 30 May 2013. Web. 10 June 2013.

<http://news.ontario.ca/mei/en/2013/05/ontario-working-with-communities-to-secure-clean-energyfuture.html>.

Government of Ontario. 2013b. "Ontario Continues to Build Smarter, More Efficient Electricity Grid."News Release. Government of Ontario, 2 July 2013. Web. 07 July 2013.

<http://news.ontario.ca/mei/en/2013/07/ontario-continues-to-build-smarter-more-efficient-electricitygrid.html>.

Hall, Allan. 2011. "Germany Pledges to Shut down All Its Nuclear Plants by 2022 following Fukushima Disaster." Mail Online. Mail Online, 31 May 2011. Web. 3 Mar. 2012. 
<http://www.dailymail.co.uk/sciencetech/article-1392359/Germany-pledges-nuclear-shutdown-2022following-Fukushima-disaster.html>.

Hamilton, T. 2009. Hydro's wind plans face stiff opposition; scarborough residents fear a 25-kilometre line of turbines would blight the bluff's landscape. Toronto Star. (2009, Oct 24). Retrieved from http://ezproxy.lib.ryerson.ca/login?url=http://search.proquest.com/docview/439620088?accountid=13 631

Heneghan, Tom. 2014. "US Wins Praise for Carbon Cuts at UN Talks, Told to Do More." Reuters. Thomson Reuters, 04 June 2014. Web. 23 June 2014.

Ibenholt, Karin. 2002. "Explaining Learning Curves for Wind Power." Energy Policy 30 (2002): 1181-189. Print.

IEA. 2013. "Executive Summary." International Energy Agency, 2013. Web. 15 Aug. 2013. <http://www.iea.org/Textbase/npsum/germany2013SUM.pdf>.

IESO. 2012. "Composition of Ontario's Electricity Supply Mix Continues to Change: Consumer Response Supports Reliability." Media Desk News Release. Independent Electricity System Operator, 6 Jan. 2012. Web. 28 Aug. 2013. <http://www.ieso.ca/imoweb/media/md_newsitem.asp?newsID=5930>.

IESO. 2014. "Ontario's Supply Mix." Error. Independent Electricity System Operator, Jan. 2014. Web. 10 Feb. 2014. <http://www.ieso.ca/Pages/Ontario\%2527s-Power-System/Supply-Mix/default.aspx>.

Jobert, Arthur, Pia Laborgne, and Solveig Mimler. 2007. "Local Acceptance of Wind Energy: Factors of Success Identified in French and German Case Studies." Energy Policy 35.5 (2007): 2751-760. Print.

Kaygusuz. K. 2009. Wind Power for a Clean and Sustainable Energy Future, Energy Sources, Part B: Economics, Planning, and Policy, 4:1, 122-133

Krogh, Carmen M.E. 2011. "Industrial Wind Turbine Development and Loss of Social Justice." Bulletin of Science, Technology \& Society 31.4 (2011): 321-33. Print.

Kilpatrick, Dean G., Ph.D. 2000. "Definitions of Public Policy and the Law." Definitions of Public Policy and the Law. Medical University of South Carolina, 2000. Web. 02 Feb. 2014.

Kitzing, Lena, Catherine Mitchell, and Poul Erik Morthorst. 2012. "Renewable Energy Policies in Europe: Converging or Diverging?" Energy Policy 51 (2012): 192-201. Print.

Kunze, C. and Busch, H. 2011. "The Social Complexity of Renewable Energy Production in the Countryside". Electronic Green Journal 1(31). Print.

Laing, David. 2013."Suzuki Elders." Suzuki Elders, 7 Mar. 2013. Web. 5 Oct. 2013.

<http://suzukielders.wordpress.com/2013/03/07/energy-from-the-wind-the-example-of-wolfe-islandwind-farm-ontario/>.

Laird, Frank N., and Christoph Stefes. 2009. "The Diverging Paths of German and United States Policies for Renewable Energy: Sources of Difference." Energy Policy 37.7 (2009): 2619-629. Print. 
Lauber, V. and Mez, L. 2006. "Renewable Electricity Policy in Germany, 1974 to 2005." Bulletin of Science, Technology \& Society 26.2: 105-20. Print.

Lehr, Ulrike, Joachim Nitsch, Marlene Kratzat, Christian Lutz, and Dietmar Edler. 2008. "Renewable Energy and Employment in Germany." Energy Policy 36.1 (2008): 108-17. Print.

The Local. 2010. "120,000 Take Stand against Nuclear Power." The Local. The Local, 25 Apr. 2010. Web. 25 June 2014.

Lopes, Sandra L. 2004. "Winds of Change: Renewable Energy and the Location of Wind Turbines in Prince Edward County, Ontario." Dissertations and Theses (2004): n. pag. Print.

Lord, Andrew. 2013. "Ontario Announces The End Of The FIT For Large-Scale Renewable Projects Environment - Canada." Ontario Announces The End Of The FIT For Large-Scale Renewable Projects Environment - Canada. Mondaq, 10 June 2013. Web. 10 June 2013.

<http://www.mondaq.com/canada/x/244052/Environmental Law/Ontario Announces the End of the FIT for LargeScale Renewable Projects $>$.

Lund, P. 2009. "Effects of Energy Policies on Industry Expansion in Renewable Energy." Renewable Energy 34.1 (2009): 53-64. Print.

Mabee, Warren E., Justine Mannion, and Tom Carpenter. 2012. "Comparing the Feed-in Tariff Incentives for Renewable Electricity in Ontario and Germany." Energy Policy 40 (2012): 480-89. Print.

Manning, Paul, and Joanna Vince. 2010. "Municipalities and the Green Energy Act: Benefits, Burdens, and Loss of Power." Willms Shier. Municipal World, Jan. 2010. < http://www.willmsshier.com/docs/eflashes/municipalities-and-the-green-energy-act-bene-fits-burdens-and-loss-of-power3.pdf?sfvrsn=12>.

McEachern, Gillian, and Kris Stevens. 2013. "Happy Birthday to the Green Energy and Green Economy Act." Thestar.com. The Toronto Star, 28 May 2013. Web. 13 Oct. 2013.

<http://www.thestar.com/opinion/commentary/2013/05/28/happy_birthday_to_the_green_energy_an d_green_economy_act.html>.

Mills, Dora A., MD, and James F. Manwell, PhD. 2012. A Brief Review of Wind Power in Denmark, Germany, Sweden, Vermont, and Maine: Possible Lessons for Massachusetts. Rep. N.p.: n.p., 2012.

Print.

Ministry of Energy. 2013. Ontario's Long-Term Energy Plan. By Ministry of Energy. Toronto: Queen's Printer of Ontario, 2013. Print.

Ministry of Research and Innovation. 2013. "Renewable Energy Boosts Ontario's Economy, Fights Climate Change." Ontario Business Report. Ministry of Research and Innovation, n.d. Web. 15 Oct. 2013. $<$ http://www.mri.gov.on.ca/obr/?p=108>.

Munday, Max, Gill Bristow, and Richard Cowell. 2011. "Wind Farms in Rural Areas: How Far Do Community Benefits from Wind Farms Represent a Local Economic Development Opportunity?" Journal of Rural Studies 27.1 (2011): 1-12. Print. 
Musall, Fabian D., and Onno Kuik. 2011."Local Acceptance of Renewable Energy - A Case Study from Southeast Germany." Energy Policy 39 (2011): 3252-260. Print.

Nelso, Susan. 2010. "Ontario Survey Finds Broad Acceptance of Wind Farms, but Communities Resist." SNL Energy Power Week Canada 2 Aug. 2010: n. pag. Print.

Newswire. 2012. "Citizens to Protest at Wind Industry Forum." Newswire, 2 Apr. 2012. Web. 3 Oct. 2013. <http://www.newswire.ca/en/story/948203/citizens-to-protest-at-wind-industry-forum>.

Ohl, Cornelia, and Marcus Eichhorn. 2010. "The Mismatch between Regional Spatial Planning for Wind Power Development in Germany and National Eligibility Criteria for Feed-in Tariffs-A Case Study in West Saxony." Land Use Policy 27.2 (2010): 243-54. Print.

Ontario Power Generation. News \& Media. 2014. OPG's Nanticoke Station Stops Burning Coal. Ontario Power Generation, 8 Jan. 2014. Web. 13 Feb. 2014. <http://www.opg.com/news-and-media/newsreleases/Documents/140108NanticokeStopBurningCoal.pdf>.

Ontario PC. 2012. "Liberals Must Act Now to Halt Development on New Wind Farms." Ontario PC, 17 July 2012. Web. 22 Sept. 2013. <http://www.ontariopc.com/news/article/liberals-must-act-now-to-haltdevelopment-on-new-wind-farms $>$.

Ontario Power Authority. 2014. "FIT Price Schedule | Ontario Power Authority - Feed-in Tariff Program." FIT Price Schedule / Ontario Power Authority - Feed-in Tariff Program. Ontario Power Authority, n.d. Web. 7 Feb. 2014.

Ontario Sustainable Energy Association. 2005. "Ontario Landowner's Guide to Wind Energy." Canadian Wind Energy Agency, 2005. Web. 22 Sept. 2013. <http://www.canwea.ca/pdf/OSEA-2005-r1.pdf>.

Ozbilen, A., I. Dincer, G.F. Naterer, and M. Aydin. 2012. "Role of Hydrogen Storage in Renewable Energy Management for Ontario." International Journal of Hydrogen Energy 37 (2012): 7343-354. Print.

Paperny, Anna M. 2010. "Scarborough Bluffs Residents Determined to Fight Wind Turbine ProjectAdd to ..." The Globe and Mail. The Globe and Mail, 16 Apr. 2010. Web. 3 Feb. 2014.

Pasqualetti, Martin J. 2004. "WIND POWER: Obstacles and Opportunities." Environment: Science and Policy for Sustainable Development 46.7 (2004): 22-38. Print.

Pergamon. 2000. "Act on Granting Priority to Renewable Energy Sources (Renewable Energy Sources Act, Germany, 2000)." Solar Energy 70.6 (2001): 489-504. Print.

Practical Law. 2013."Electricity Regulation in Germany: Overview." Practical Law. Thomson Reuters, 1 Apr. 2013. Web. 21 Sept. 2013. <http://us.practicallaw.com/5-524-0808>.

Rajpurohit, B.s., S.n. Singh, and Istvan Erlich. 2008."Wind Power in Electricity Markets: Key Issues and Challenges." International Journal of Energy Technology and Policy 6.3 (2008): 196-211. Print. 
Radwanski, Adam. 2013. "Ontario Backs Away from Plans to Buy New Nuclear Reactors Add to ..." The Globe and Mail. The Globe and Mail, 10 Oct. 2013. Web. 20 Oct. 2013.

Renewables International. 2014."New German Energy Plan: Keep Costs down by Missing Targets." Renewables International, 18 Jan. 2014. Web. 11 Feb. 2014.

Roome, Nigel John, and Ronald Bergin. 2006. "Sustainable Development in an Industrial Enterprise: the Case of Ontario Hydro." Business Process Management Journal 12.6 (2006): 696-721. Print.

Sahni, Nalin, and David P. McCutcheon. 2013."Canada: Environmental Review Tribunal Rejects First Renewable Energy Approval." Environmental Review Tribunal Rejects First Renewable Energy Approval. Mondaq/Dentons, 31 July 2013. Web. 22 Aug. 2013.

<http://www.mondaq.com/canada/x/255358/Environmental Review Tribunal Rejects First Renewable Energy Approval>.

Saxe, Dianne. 2013a. "Wainfleet's Anti-wind Turbine By-law Invalid." Environmental Law and Litigation RSS. Dianne Saxe Law Office, 6 Mar. 2013. Web. 14 July 2013. <http://envirolaw.com/wainfleetsantiwind-turbine-bylaw-invalid/>.

Saxe, Dianne. 2013b. "Canada: Municipality Can't Bring Charter Challenge To Wind Approval Rules." Municipality Can't Bring Charter Challenge To Wind Approval Rules. Mondaq/Saxe Law Office, 22 July 2013. Web. 16 Aug. 2013. <http://www.mondaq.com/canada/x/252634/Environmental Law/Municipality Can't Bring Charter Challenge To Wind Approval Rules>.

Saxe, Dianne. 2013c. "Keep Green Energy, Oppose Bill 39." Environmental Law and Litigation RSS. Dianne Saxe Law Office, 17 Apr. 2013. Web. 15 July 2013. <http://envirolaw.com/important-noticesupport-renewable-energy/>.

Scarborough Mirror. 2013. Scarborough could have been home to wind turbines in lake: Toronto hydro. 2013. The Scarborough Mirror. (2013, Jun 06). Retrieved from http://ezproxy.lib.ryerson.ca/login?url=http://search.proquest.com/docview/1365718285?accountid=1 3631

Schaber, Katrin, Florian Steinke, and Thomas Hamacher. 2012. "Transmission Grid Extensions for the Integration of Variable Renewable Energies in Europe: Who Benefits Where?" Energy Policy 43 (2012): 123-35. Print.

Schroeder, Andreas, Pao-Yu Oei, Aram Sander, Lisa Hankel, and Lilian Charlotte Laurisch. 2013. "The Integration of Renewable Energies into the German Transmission Grid-A Scenario Comparison." Energy Policy 61 (2013): 140-50. Print.

Sovacool, B. 2008. "Renewable Energy: Economically Sound, Politically Difficult." The Electricity Journal 21.5 (2008): 18-29. Print.

Spears, J. 2008. Offshore wind farm stirs up a tempest; 1,000 residents, activists face off over proposal for scarborough bluffs. (2008, Nov 25) Toronto Star. Retrieved from http://ezproxy.lib.ryerson.ca/login?url=http://search.proquest.com/docview/439510844?accountid=13 631 
Spears, John. 2013. "Offshore Wind Moratorium Mixed Policy and Politics, Lawyer Argues." Thestar.com. The Toronto Star, 22 Mar. 2013. Web. 15 Aug. 2013.

<http://www.thestar.com/business/tech_news/2013/03/22/offshore_wind_moratorium_mixed_policy_ and_politics_lawyer_argues.html>.

Statistics Canada. 2012."Population by Year, by Province and Territory (Number)." Government of Canada, Statistics Canada. Government of Canada, 27 Sept. 2012. Web. 15 Sept. 2013. <http://www.statcan.gc.ca/tables-tableaux/sum-som/l01/cst01/demo02a-eng.htm>.

Stokes, Leah C. 2013. "The Politics of Renewable Energy Policies: The Case of Feed-in Tariffs in Ontario, Canada." Energy Policy 56 (2013): 490-500. Print.

Talaga, T. 2011. Offshore wind projects scrapped. Toronto Star. (2011, Feb 12). Retrieved from http://ezproxy.lib.ryerson.ca/login?url=http://search.proquest.com/docview/851362443?accountid=13 631

Taylor, Allan. 2011. "Protesters Disrupt German Nuclear Waste Shipment." The Atlantic. Atlantic Media Company, 28 Nov. 2011. Web. 25 June 2014.

Taylor, Jennifer, Valerie Kitchell, and Julia Balabanowizcz. 2008. "A Fine Act to Follow." Alternatives 34.6 (2008): 18-19. Print.

The Economist. 2013. "Troubled Turn." Germany's Energy Reform. The Economist, 9 Feb. 2013. Web. 22 May 2013.

The Electricity Journal. 1996. "Ontario Panel Recommends Privatization, Competition." The Electricity Journal August/September (1996): 7-8. Print.

The World Bank. 2013a. "Electric Power Consumption (kWh per Capita)." Data. The World Bank, n.d. Web. 24 Sept. 2013. <http://data.worldbank.org/indicator/EG.USE.ELEC.KH.PC>.

The World Bank. 2013b."Population, Total." Data. The World Bank, n.d. Web. 24 Sept. 2013. <http://data.worldbank.org/indicator/SP.POP.TOTL>.

Timmins, Thomas J., and Gatlin Smeijers. 2013."Canada: Wainfleet Wind Energy Inc. v. Township Of Wainfleet: Case Comment." Wainfleet Wind Energy Inc. v. Township Of Wainfleet: Case Comment. Mondaq/Gowlings, 16 July 2013. Web. 07 Aug. 2013.

<http://www.mondaq.com/canada/x/251092/Renewables/Wainfleet Wind Energy Inc v Township Of Wainfleet Case Comment>.

Toke, D., S. Breukers, and M. Wolsink. 2008."Wind Power Deployment Outcomes: How Can We Account for the Differences?" Renewable and Sustainable Energy Reviews 12.4 (2008): 1129-147. Print.

Township of Frontenac Islands. 2006. "Frontenac Islands." Amenities Agreement. Township of Frontenac Islands, 2006. Web. 29 Mar. 2012. <http://municipality.frontenacislands.on.ca/?q=amenitiesagreement>. 
Trebilcock, Michael J., and Roy Hrab. 2005. "Electricity Restructuring in Ontario." The Electricity Journal 26.1 (2005): 123-46. Print.

Valentine, Scott Victor. 2010. "Canada's Constitutional Separation of (wind) Power." Energy Policy 38.4 (2010): 1918-930. Print.

Walker, Sven. 2013. "Renewable Energy Approvals \& Appeals for Wind \& Solar Projects in Ontario." Dale \& Lessman LLP. Dale \& Lessman LLP, 25 Mar. 2013. Web. 5 Feb. 2014.

$<$ http://dalelessmann.com/en/news/blog/renewable-energy-approvals-appeals-wind-solar-projectsontario>.

Wilson, Robert. 2013. "Wind Energy Growing Faster than Coal in China: False Math." The Energy Collective. The Energy Collective, 20 May 2013. Web. 20 Sept. 2013.

<http://theenergycollective.com/robertwilson190/226761/wind-power-growing-faster-coal-chinazombie-fact>.

Wüstenhagen, Rolf, Maarten Wolsink, and Mary Jean Bürer. 2007. "Social Acceptance of Renewable Energy Innovation: An Introduction to the Concept." Energy Policy 35.5 (2007): 2683-691. Print.

Yatchew, A. and Baziliauskas, A. 2011. Ontario feed-in-tariff programs, Energy Policy, Volume 39, Issue 7, July 2011, Pages 3885-3893, ISSN 0301-4215, 10.1016/j.enpol.2011.01.033.

(http://www.sciencedirect.com/science/article/pii/S0301421511000437)

Zoellner, Jan, Petra Schweizer-Ries, and Christin Wemheuer. 2008. "Public Acceptance of Renewable Energies: Results from Case Studies in Germany." Energy Policy 36.11 (2008): 4136-141. Print. 